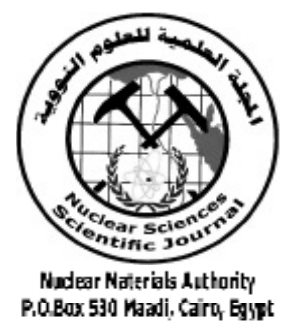

ISSN 2314-5609

Nuclear Sciences Scientific Journal

vol. 3 , p $27-53$

2014

\title{
PETROGENSIS AND MINERALOGICAL CHARACTERIZATION OF PEGMATITES FROM KHOUR ABALEA, SOUTH EASTERN DESERT, EGYPT
}

\author{
MOSTAFA E. DARWISH \\ Nuclear Materials Authority
}

\begin{abstract}
Khour Abalea in Abu Rusheid area is located at the midst part of the cataclastic rocks having U-shaped It was formed as a result of deep strike-slip faults, some forming shear zone in some trends. Two forms of pegmatites have been distinguished (pockets and veins) occurring within the cataclastic rocks as hosted rocks. Petrographically, they consist of quartz, orthoclase, microcline and micas.

The identified minerals in the studied pegmatites can be grouped into primary uranium minerals (uraninite), secondary uranium minerals (kasolite, uranophane and meta-autunite), thorium minerals (thorite and uranothorite), the niobium-tantalum minerals (columbite, ferro-columbite, samarskite, euxenite and fergusonite), the accessories (zircon, monazite, cassiterite, pyrite and fluorite) and mica (muscovite, phlogopite and fluor-phlogopite) as well as the opaques (hematite and goethite).

Geochemically, the studied pegmatite (S-type) are calc-alkaline and peraluminous in nature. It is highly fractionated possibly due to hydrothermal alterations. The REEs display clear tetrad effect of M-type accompanied with relative enrichment of the HREE over the LREE and marked negative Eu anomaly $\left(\mathrm{Eu} / \mathrm{Eu}^{*}=0.03\right.$ to 0.36$)$. The calculated tetrad effect in the pegmatite demonstrates clear tendency towards the ratios of the common isovalents such as $\mathrm{Zr} / \mathrm{Hf}, \mathrm{Nb} / \mathrm{Ta}$ and $\mathrm{Y} / \mathrm{Ho}$. However, the tetrad effect seems not to be mutual with the content of $\mathrm{Na} 2 \mathrm{O}$ and $\mathrm{Rb} / \mathrm{Sr}$. The absence of coherence between tetrad effect and soda or potassic contents may indicate insignificant role of the Na- or K-metasomatism in developing the tetrad effect.

Detailed spectrometric survey of the study pegmatite revealed their enrichment of eU (49-306 ppm) and eTh $(76-634 \mathrm{ppm})$ and the potential anomalous radioactivity is attributed to both magmatic and hydrothermal processes.
\end{abstract}

\section{INTRODUCTION}

The petrogenetic models of pegmatites in recent years have been made based on a combination of field and laboratory studies. The broad scale characteristics of pegmatite fields, together with detailed work on individual pegmatite types, have enabled the development of a comprehensive classification of pegmatite and predictive models for the assessment of pegmatite (Černý, 1991; El Assy et al.,1993 and 1997; Ibrahim et al.,1996; El Dougdoug et al.,1997; Salem et al.,1998; Ibrahim,1999; Ibrahim et al.,2001; Ahmed ,2002; Abdalla and El Afandy,2003; Sosa et al., 2002; Abd El-Naby and Saleh ,2003; Surour et al., 2004; Zagorsky and Peretyazhko, 2006; Abd El Wahed et al., 2007 ; Saleh et al., 2007;Raslan et al., 2010 a,b and Ragab,2010).

There are three main theories behind pegmatite formation: 
(1) Metamorphic theory: The pegmatite fluids are created by dewatering of metamorphic rocks, particularly felsic gneiss, to liberate the right constituents and water at right temperature. some elements and fluids may be literally sweated out of a rock complex during metamorphism well known because it contains crystals of many different minerals. This rock is pushed up as large veins of magma that was rich in volatile elements resulting in large crystals, usually surrounded by granitic rocks ( Joliff et al., 1992; Webster et al.,1997 and Fuertes-Fuente et al., 2000).

(2) Magmatic theory: The pegmatite tend to occur in aureoles of granites in most cases and often closely matching the compositions of nearby granites represent exsolved granitic material which crystallizes in the country rocks (London, 1992).

(3) metasomatic theory: The pegmatite, in a few cases, could be explained by the action of hot alteration fluids upon a rock mass, with bulk chemical and textural change, London (op.cit) and Dipak et al. (2006).
Many geochemical studies has been demonstrated that such volatiles as $(\mathrm{F}, \mathrm{B}, \mathrm{Li}, \mathrm{P})$ have a significant influence on the evolution of the pegmatite magma, the temperatures of the solidus and liquidus of the magma, the viscosity of the silicate melt, the crystallization sequence of minerals and also on the partition behavior of trace elements between fluid and melt (Dingwell et al., 1998; Bai and Van Groas, 1999).

The present work aims to study the geochemical characteristics of Khour Abalea pegmatite in details through focus on the mineralogical and spectrometric studies to elucidate the petrogenesis of the pegmatites that scattered in the Khour.

\section{GEOLOGICAL SETTING}

According to Saleh (1997) and Ibrahim et al. (2002 and 2006), the tectono-stratigraphic sequence of the Precambrian rock units of Abu Rusheid area are arranged in the following order from the oldest to youngest into(Fig.1): (1) Metagabbros; (2) Ophiolitic mélange consist-

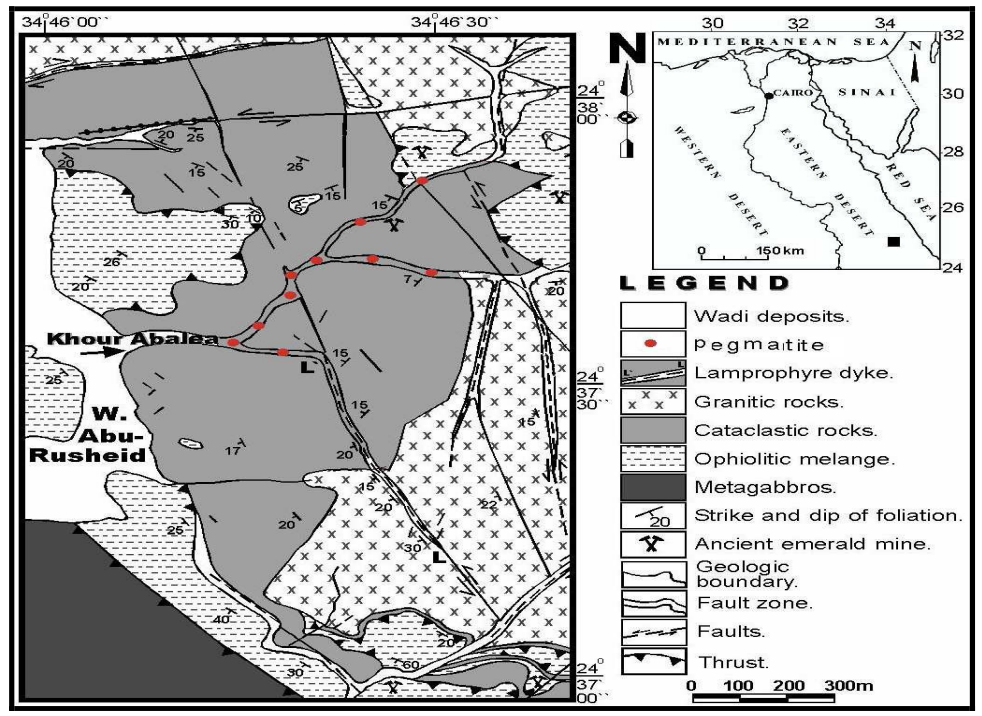

Fig. 1 : Geologic map of Abu Rusheid- Khour Abalea area southeastern Desert, Egypt (After Ibrahim et al., 2006) 
ing of ultramafic rocks and layered metagabbros set in metasediment matrix; (3) Cataclastic rocks, consisting of (protomylonites, mylonites, ultramylonites and silicified ultramylonites rocks); (4) Granitic rocks; (5) Post granitic dykes and veins (lamprophyre dykes and pegmatite veins).

Some workers as Hassan (1973); Abdel Monem and Hurley (1979) and Saleh (1997) consider Abu Rusheid cataclastic rocks as psammitic gneisses, whereas others considered these rocks as cataclastic rocks composed mainly of protomylonites, mylonites, ultramylonites and quartzite with gradational contacts (Ibrahim et al., 2002, 2004, 2006, 2007 a, b ,c).

The cataclastic rocks are highly sheared, foliated, banded and folded especially at their contacts with the ophiolitic mélange. They are characterized by high contents of $\mathrm{Nb}, \mathrm{Ta}, \mathrm{Sn}$, $\mathrm{Pb}$ and $\mathrm{Zr}$ (Ibrahim et al., 2004). They are intersected by two sets of shear zones (NNWSSE \& ENE-WSW).

At the northern and southern parts of Abu Rusheid area, the granitic rocks are mainly mylonitic two mica granite and biotite granite, respectively. At the end of Khour Abalea, they occur as small intrusion of muscovite granite. They occur as small to moderate bodies of low hill masses and extend out of the mylonitic rocks, as large masses, with high elevation. The granitic rocks carry a roof pendant of mylonitic rocks (Saleh, 1997 and Ibrahim et al., 2004).

The basement rocks of Abu Rusheid area are cross-cut by various lamprophyre dykes and pegmatite veins. Lamprophyres dykes are emplaced along the two shear zones and bearing mineralization. The NNW-SSE lamprophyre dykes host $\mathrm{Zn}, \mathrm{U}, \mathrm{Cu}$, REEs and $\mathrm{Sn}$ mineralization, whereas those trending ENEWSW lamprophyre dykes contain $\mathrm{Nb}-\mathrm{Ta}$, Th, $\mathrm{U}$ and $\mathrm{Zn}$ minerals (Ibrahim et al., 2004 and 2007 a, b, c ).

It can be noticed that, two forms of peg- matite under study (pockets and veins) hosted in the cataclastic rocks mainly mylonite rocks. It is so easy to distinguish between the two forms. The first one formed by segregation of the host rocks, without sharp contact with its surrounding, while the second form has a gradational contact. Petrographically, they consist of quartz, orthoclase, microcline and micas (Li-rich mica, zinnwaldite, after Ibrahim et al., 2002). Pegmatite pockets occur as flat lenses range from $5 \mathrm{~m}$ to $10 \mathrm{~m}$ in length, but pegmatite vines rang from $50 \mathrm{~cm}$ to $5 \mathrm{~m}$ in length especially at the margin of cataclastic rocks at NE-SW trend.

Khour Abalea is a U-shaped body and located at the midst part of the mylonitic rocks (Fig.2). It was formed as a result of deep strike-slip faults, some forming shear zone in some trends. These faults trends ENE-WSW, NNW-SSE, N-S and NE to NNE-SW to SSW, respectively (Ibrahim et al., 2004). The path of the studied Khour is containing pegmatite and quartz veins in boudin forms (Fig.3) rich in poly- or multi-mineralization as well as pockets showing flow structure with mylonitic rocks in shoulder of the Khour (Fig.4). There is gradational contact between pegmatite and host rocks (mylonite rocks) in the floor of the Khour. Pegmatites are bearing cassiterite, thorite, columbite-tantalite and uranium mineralization. The intersection between Khour Abalea and lamprophyre dyke show the tectonic

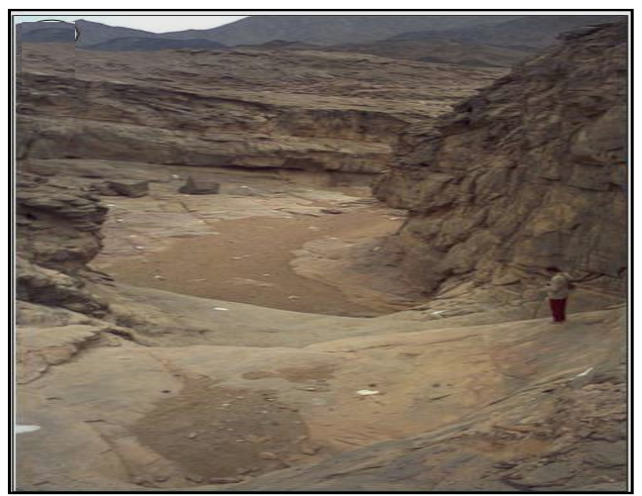

Fig. 2: General view of Khour Abalea along Abu Rusheid area. Photo is looking to $\mathrm{N}$ 


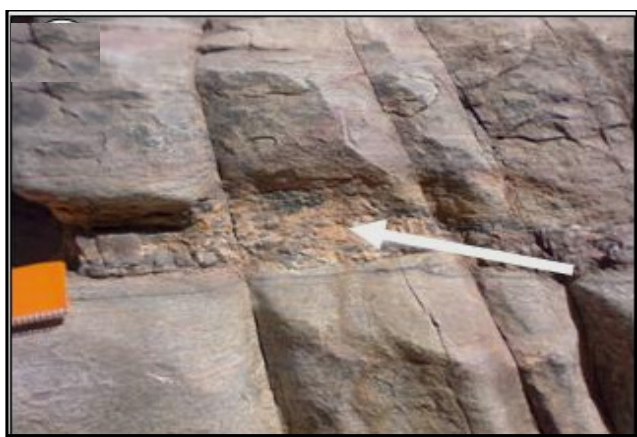

Fig.3 : Pegmatite vein boudin in cataclastic rocks, Khour Abalea. Photo is looking to $\mathrm{N}$

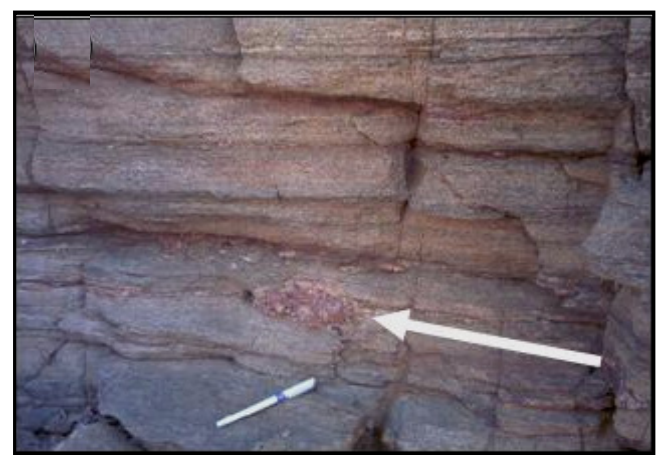

Fig.4: Pegmatite pockets in cataclastic rocks in shoulder of Khour Abalea. Photo is looking to $\mathrm{N}$

nature of the Khour and illustrated the ductile discontinuous shearing (Ibrahim et al. (2002, 2004) and Rashed (2005).

\section{ANALYTICAL TECHNIQUES}

Sixteen samples representing the studied pegmatite were collected. The samples which show high radioactivity level were crushed and their heavy minerals separated using Frantz Isodynamic Separator and bromoform. Both the obtained magnetic and non-magnetic fraction was investigated under binocular microscope. Some individual grains were picked and analyzed by powder X-ray diffraction (XRD) technique, Nuclear Materials Authority (NMA), Cairo, Egypt. The major oxides are analyzed using conventional wet chemical techniques of Shapiro and Brannock (1962). The X-ray fluorescence technique, (XRF) is used to determine the trace element contents using PHILIPS X'Unique-II spectrometer as well as rare earth elements are measured by ICP-MS spectrometry in the laboratories of the Egyptian Atomic Energy.

\section{MINERALOGY}

The mineralogical study of five composite samples representing pegmatite are selected from the pockets and veins which cross- cut the mylonitic rocks at Khour Abalea. They are carried out to identify the radioactive minerals as well as their origin and source. The identified minerals in this investigation are classified as follows:

\section{Uranium Minerals}

\section{Primary uranium minerals Uraninite ( $\left.\mathrm{UO}_{2}\right)$}

It is identified from the pegmatite samples that distributed as pockets nearly closed to the shear zone for the first time at Khour Abalea. uraninite associated with zircon is identified by the binocular microscope and X-ray diffraction analysis (Fig.5). It appears as disseminated coarse-grains or aggregates. Uraninite has some crystals of cubic form, rounded to subrounded crystal faces, dark grey in colour (Figs.6\&7) having metallic luster. It occurs as a primary constituent in pegmatite. It is altered readily to numerous secondary hydrated oxides, carbonates, sulphates, phosphates, arsenates, vanadates and silicates of uranium and other elements (Gorman and Nuffield, 1955).

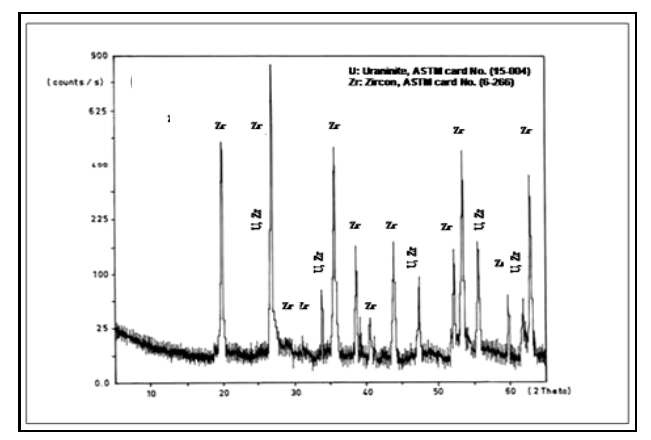

Fig.5: X-ray diffractogram of uraninite associated with zircon 


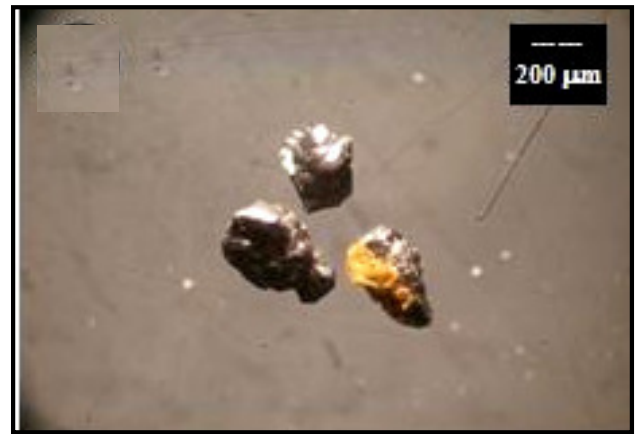

Fig.6: Photomicrograph of dark grey of uraninite grains associated with zircon

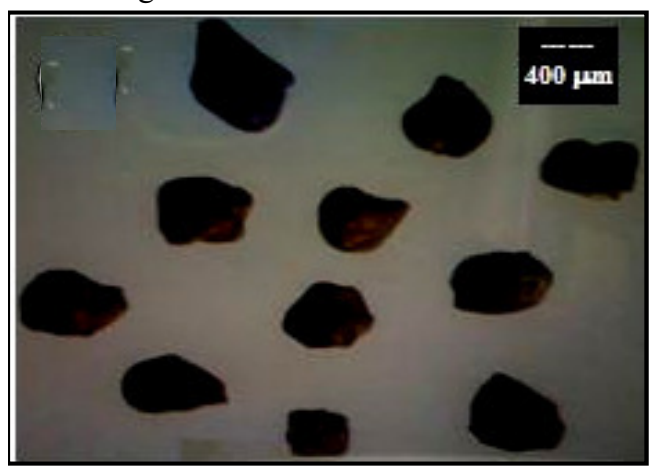

Fig.7 : Dark brown uraninite grains

\section{Secondary uranium minerals}

\section{Kasolite [ $\left.\mathrm{Pb}\left(\mathrm{UO}_{2}\right) \mathrm{SiO}_{4} \mathrm{H}_{2} \mathrm{O}\right]$}

It is common secondary uranium mineral in the studied pegmatite. Figure (8) shows the XRD pattern of the studied kasolite associated with muscovite, albite and clinochlore. Microscopically, kasolite occurs as massive granular masses having resinous to greasy luster and lemon yellow colour, (Fig. 9). Dawood et al., (2010) concluded that the fluoride and carbonate complexes played a significant role in the formation of kasolite. pre-existing uranium-bearing metamectized accessory minerals such U-rich thorite and zircon reacted with high temperature hydrothermal solutions to form urano-fluoride complexes at reducing conditions. When the fluids approached the surface passing through fracture system, the oxygen fugacity $(f \mathrm{O} 2)$ and the $\mathrm{pH}$ increased because of the loss of volatile components.
At these conditions, uranous fluorides would convert to uranyle fluoride complexes $\mathrm{UO}_{2} \mathrm{~F}_{3}$. Further decrease in temperature was associated with the decay of the activity of fluorine ion by the dilution of hydrothermal solutions and precipitation of fluorite. At this condition, uranyle-carbonate complexes are favoured. These complexes are combined later with silica and lead to form kasolite.

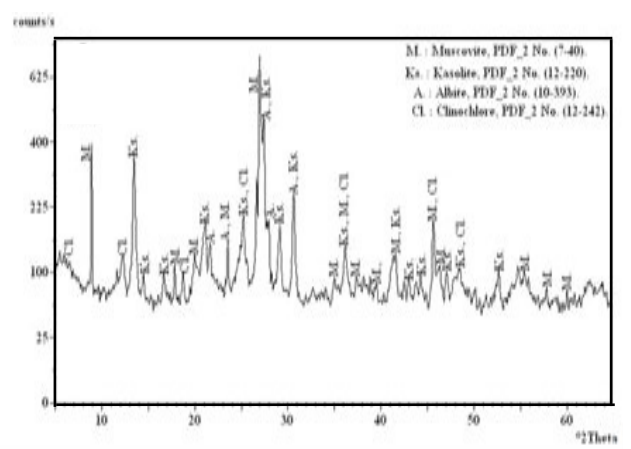

Fig.8: X-ray diffractogram of kasolite mineral associated with muscovite, albite and clinochlore minerals

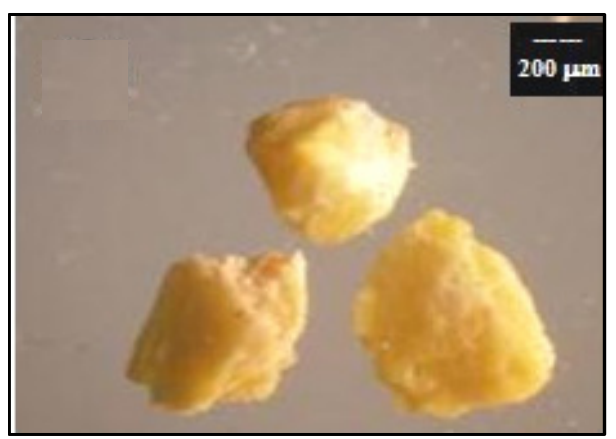

Fig.9: Lemon yellow kasolite grains

\section{Uranophane $\left(\mathrm{CaO} .2 \mathrm{UO}_{3} \cdot 2 \mathrm{SiO}_{2} \cdot 6 \mathrm{H}_{2} \mathrm{O}\right)$}

It is an alteration product of uraninite and the chief constituent of the outer silicate zone of the gummite type of uraninite alteration. It is dimorphs with beta-uranophane (Gorman and Nuffield, 1955). It represents the most abundant and widely distributed of various uranium silicate composite of a hydrate $\mathrm{Ca}$, $\mathrm{U}$ silicates. Most uranophane appears to be of supergene origin in the oxidation zones (Heinrich, 1958). Uranophane identified by 
XRD analysis (Fig. 10) and under the binocular microscope showed that its grains are present as massive radiated and tufted aggregates as well as dense microcrystalline masses. The grains are very soft with different grades of yellow colour (Fig.11).

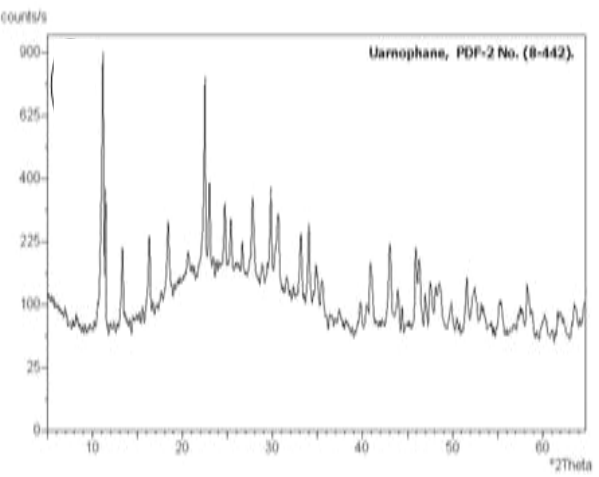

Fig. 10: X-ray diffractogram of uranophane mineral

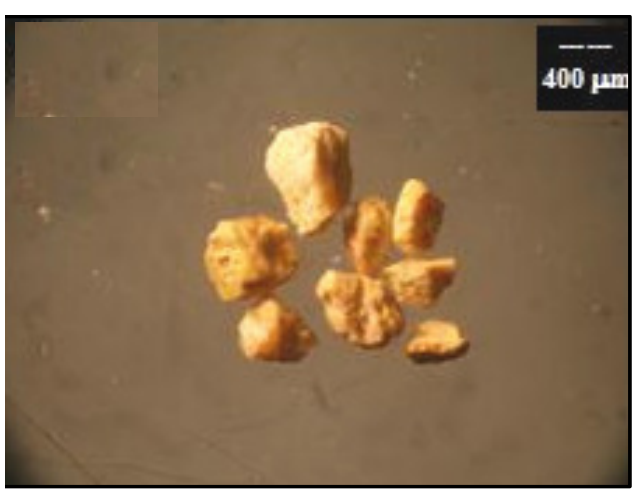

Fig.11: Yellow uranophane grains

\section{Meta-autunite Ca $\left(\mathrm{UO}_{2}\right)_{2}\left(\mathrm{PO}_{4}\right) 2.2-6\left(\mathrm{H}_{2} \mathrm{O}\right)$}

It is a dehydration product of its close cousin, autunite. Meta-autunite and autunite are similar in their hydration/ dehydration capabilities. It can be found in nature, possibly formed without going through the autunite phase. Meta-autunite is detected in the investigated pegmatite by XRD analysis (Fig.12). Its crystals have sub-parallel growth and grading into fan-like aggregates. It is pale yellowish green and strained brown in colour (Fig.13).

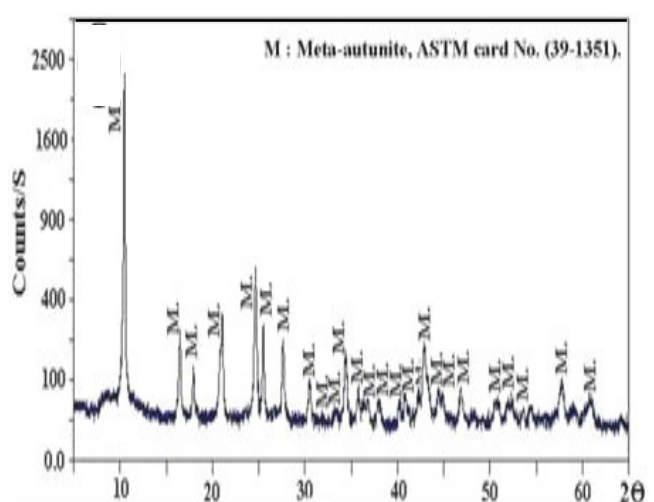

Fig. 12: X-ray diffractogram of meta-autunite mineral

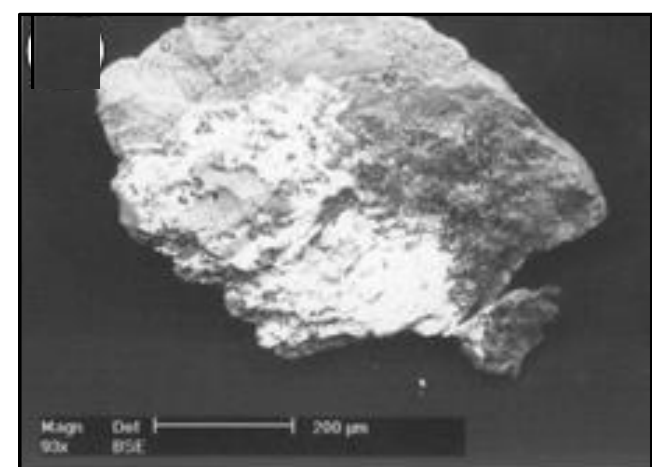

Fig. 13 : Meta-autunite grain

\section{Thorium Minerals}

\section{Thorite $\left(\mathrm{ThSiO}_{4}\right)$}

It occurs as metamectized short prismatic crystals exhibiting deep brownish colour in the studied pegmatite and confirmed by x-ray diffraction (Fig.14). Some crystals exhibit the bipyramidal habit, like zircon, where the prism faces are diminished. It is characterized by reddish brown (Fig.15) or yellow colour in polarized light as well as isotropic character due to metamictization. It is commonly associated with zircon, monazite, fergusonite, fluorite and uraninite where all induce high radioactivity. Thorite is mostly of high temperature hydrothermal origin. It is commonly metamict and hydrated making it optically isotropic and amorphous. 


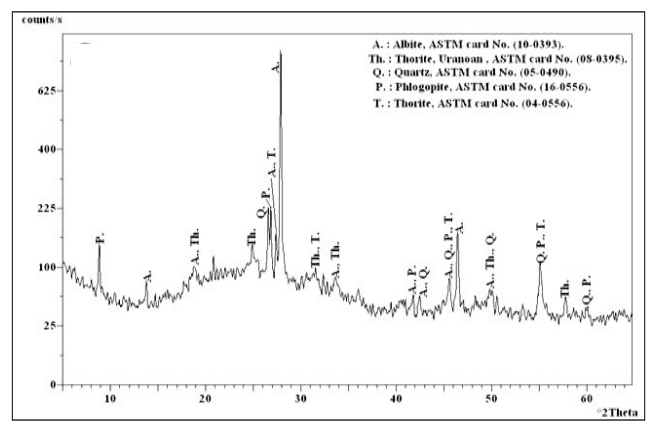

Fig. 14: X-ray diffractogram of thorite and uranothorite minerals

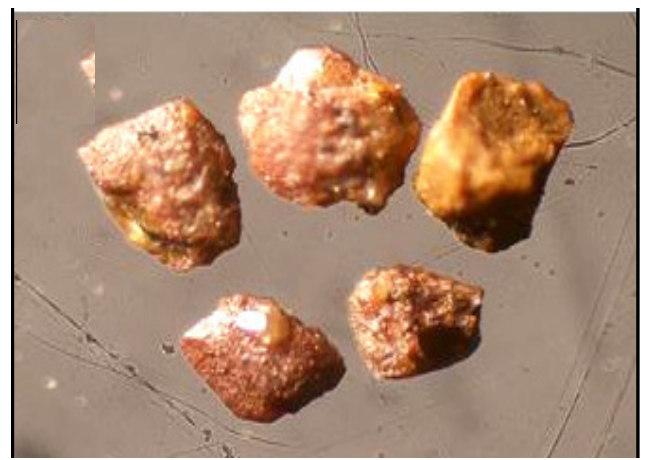

Fig. 15: Reddish brown thorite grains

\section{Uranothorite $\left[(\mathrm{Th}, \mathrm{U}, \mathrm{Ce}) \mathrm{SiO}_{4}\right]$}

It is a uranium-rich variety of thorite, containing up to half of the thorium replaced by uranium. It occurs as minute crystals associated with albite, thorite and quartz in the studied pegmatite (Fig.14). Uranothorite have crystals with dark grass green (Fig.16) transparent and well formed euhedral prisms. It is associated with zircon and thorite. It forms a solid solution series with uraninite in which uranium atoms in the crystal structure.

\section{Niobium - Tantalum Minerals}

Niobium-tantalum minerals are recorded in Khour Abalea pegmatite in spite of their extremely low abundance in the rocks.

\section{Columbite (Fe, Mn )(Nb,Ta ) $)_{2} \mathbf{O}_{6}$}

It has been recorded in the studied pegmatite. It occurs as black coloured anhedral

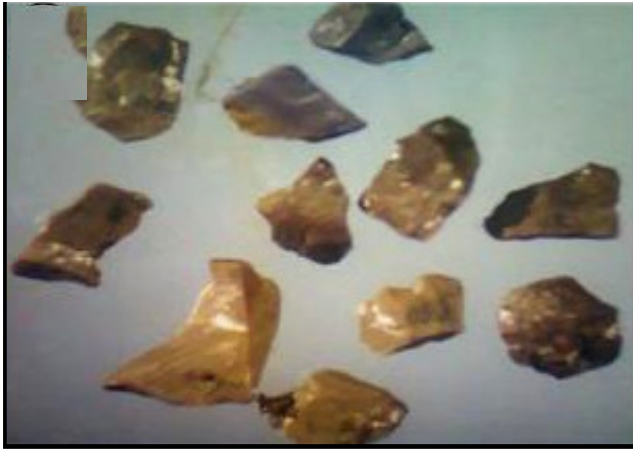

Fig.16: Dark grass green prisms from uranothorite grains

crystals with sub-metallic to resinous luster and identified by using XRD analysis (Fig. 17 \&18). Abdalla et al. (1998) explained the columbite associated with pegmatite pods at Abu Rusheid area ranges in composition between $\mathrm{Fe} \mathrm{Nb}_{2} \mathrm{O}_{6}$ and $\mathrm{Mn} \mathrm{Nb}_{2} \mathrm{O}_{6}$. They mentioned also that columbite is characterized by high Ti and $\mathrm{U}$ and low Ta contents. However columbite can be attributed to their development from fluids undergoing normal pegmatitic fractionation. This explanation is confirmed by the occurrence of some pegmatitic pods which contain coarse columbite grains $(\sim 2 \mathrm{~cm})$.

\section{Ferrocolumbite $\left(\mathrm{Fe}^{++} \mathrm{Nb}_{2} \mathrm{O}_{6}\right)$}

It is recorded in the studied pegmatite as dark brown or pale greenish coloured (Fig.19

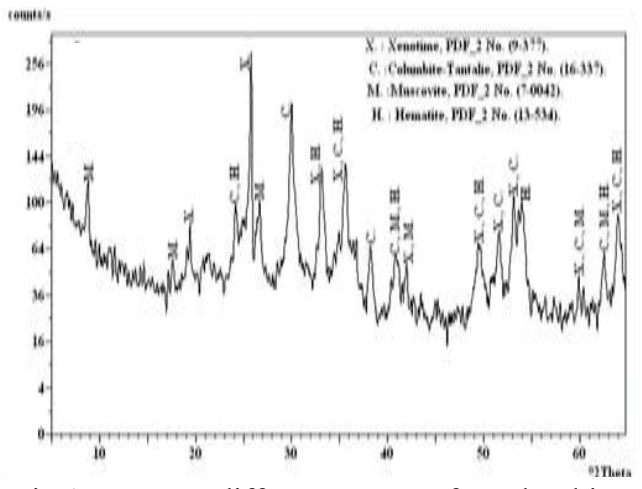

Fig.17:X-ray diffractogram of columbite associated with xenotime, muscovite and hematite minerals 
\&20) with anhedral crystals and sub-metallic luster.

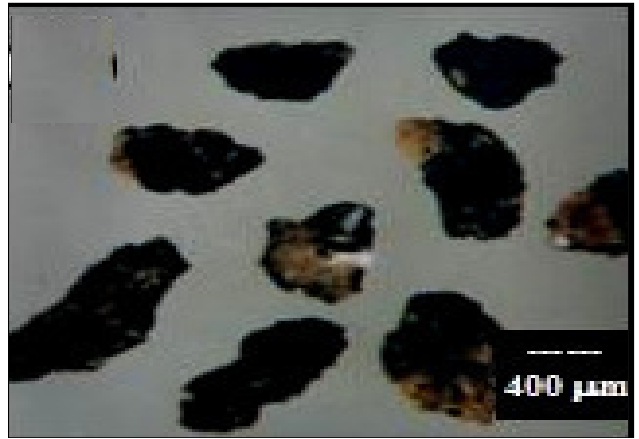

Fig. 18: Image of columbite

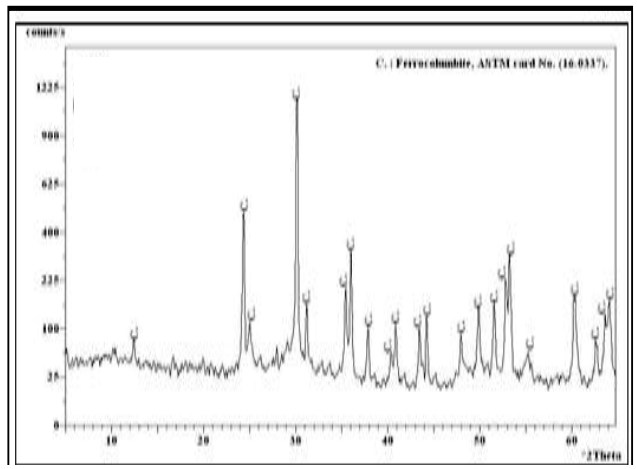

Fig. 19:X-raydiffractogramofferrocolumbite minerals

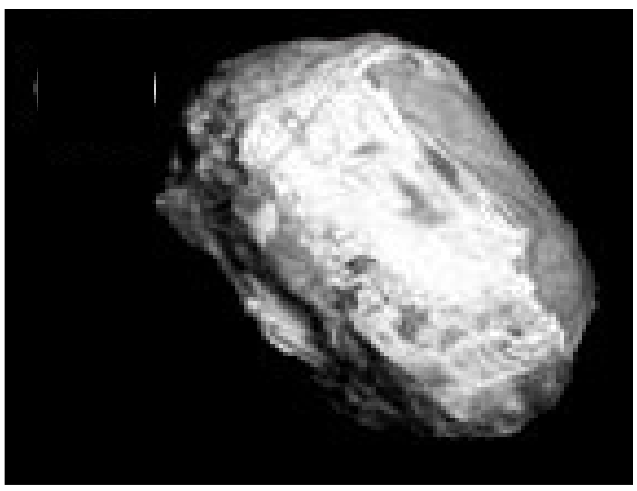

Fig. 20: Image of ferrocolumbite

\section{Samarskite}

It is a radioactive rare earth mineral series which includes samarskite -(Y) with formula $\left(\mathrm{YFe}^{3+} \mathrm{Fe}^{2+} \mathrm{U}, \mathrm{Th}, \mathrm{Ca}\right)_{2}(\mathrm{Nb}, \mathrm{Ta})_{2} \mathrm{O}_{8}$ and samar- skite $-(\mathrm{Yb})$ with formula $\left(\mathrm{YbFe}^{3+}\right)_{2}(\mathrm{Nb}, \mathrm{Ta})_{2} \mathrm{O}_{8}$ .The empirical formula of the homogenous variety of samarskite in the study pegmatite is calculated to be ( $\left.\mathrm{Y}, \mathrm{Fe}^{2+}, \mathrm{U}, \mathrm{REE}\right)(\mathrm{Nb}, \mathrm{Ta})$ $\mathrm{O}_{4}$ (Ibrahim, 1999). Samarskite crystallizes in the orthorhombic-bipyramidal class as black to yellowish brown (Figs.21\&22) stubby prisms although it is typically found as anhedral masses.

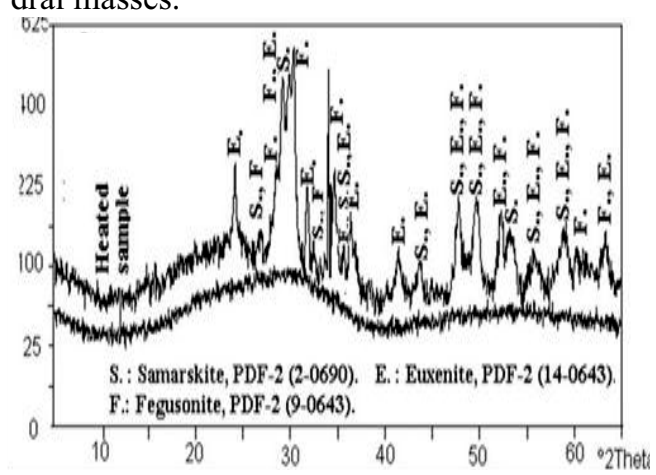

Fig. 21: X-ray diffractogram of samarskite, euxenite and fergusonite minerals

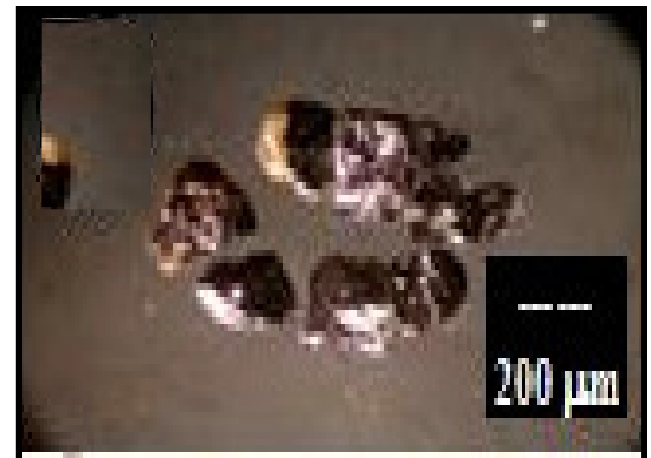

Fig. 22: Yellowish brown samarskite grains

\section{Euxenite [(Y. Ce, Ca, U, Th) (Nb, Ta, Ti) ${ }_{2} \mathrm{O}_{4} \mathrm{l}$}

It is a complex oxide mineral, a niobatetitanate that forms hard, brilliant black crystals and masses in pegmatites and associated with quartz, feldspars, columbite, tantalite, monazite and other rare earth minerals. Euxenite is a brownish black mineral with a metallic luster and reddish brown streak, its fracture is concoidal to sub-concoidal (Figs. 21\&23). 


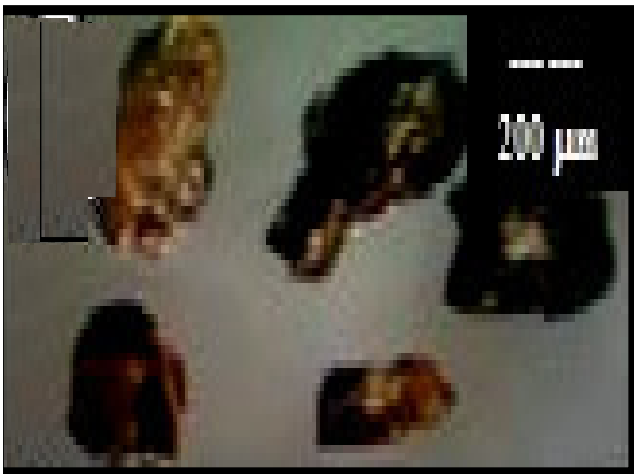

Fig. 23 : Yellow euxenite grains

\section{Fergusonite $\left[(\mathrm{Y}, \mathrm{Er})(\mathrm{Nb}, \mathrm{Ta}, \mathrm{Ti}) \mathrm{O}_{4}\right]$}

It is considered as one of the complex oxides of the radioactive minerals being reported as tetragonal, but the synthetic one is monoclinic (Ferguson, 1955). The occurrence of fergusonite is essentially confined to granites and pegmatites usually in association with combinations of allanite, zircon, monazite, euxenite, and other rare-earth minerals (Heinrich, 1962). The X-ray diffraction detected fergusonite mineral associated with euxenite, columbite and samarskite (Fig. 21). Fergusonite is recorded in the studied pegmatite as anhedral form with brown colour, its luster range from translucent in brown shades to glassy and the streak is grey to brown (Fig. 24).

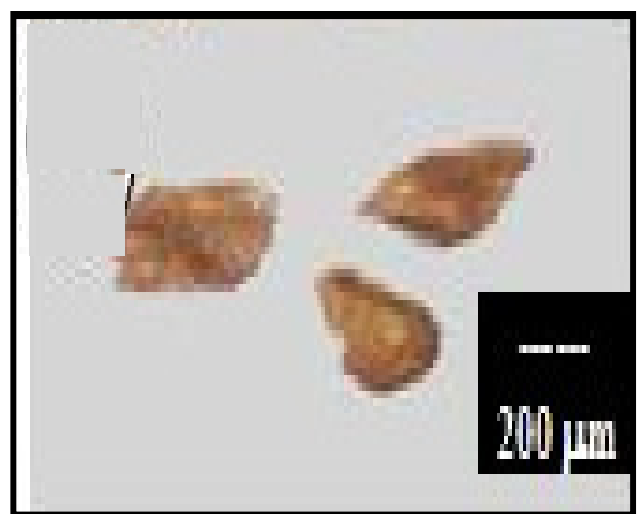

Fig. 24: Anhedral brown fergusonite grains

\section{The Accessory Minerals}

\section{Zircon $\left(\mathrm{ZrSiO}_{4}\right)$}

It represents the main constituent in the separated bulk heavy fraction of the studied pegmatite. It is remarkably resistant to attrition and alteration. A unique radioactive type of zircon occurs in part of the cataclastic rocks which are the basal unit of the metamorphic rock succession in Khour Abalea. This type known as mud zircon (Figs.25\&26) recorded in the investigated pegmatite. The recorded zircon particles show pronounced increase in grain size, overgrowth, outgrowth, crystal aggregation and multiple growths. These features resulted from the addition of zirconium transported by the metasomatic agents from the underlying part of cataclastic rock on to both the pre-existing zircon and the newly formed crystals. This indicates that zircon was leached out from cataclastic rocks and added to the studied pegmatite by the rising metasomatic agents.

\section{Monazite (Ce,La,Pr,Nd,Th,Y)(PO $\mathrm{PiO}_{4}$ )}

Monazite is brown to reddish brown in color and usually forms early in the crystallization sequence of pegmatite but may persist until the core margin/pocket zones of some pegmatite (Simmons et al., 2003). Ce-monazite is predominant in the studied pegmatite. It occurs in association with xenotime, colum-

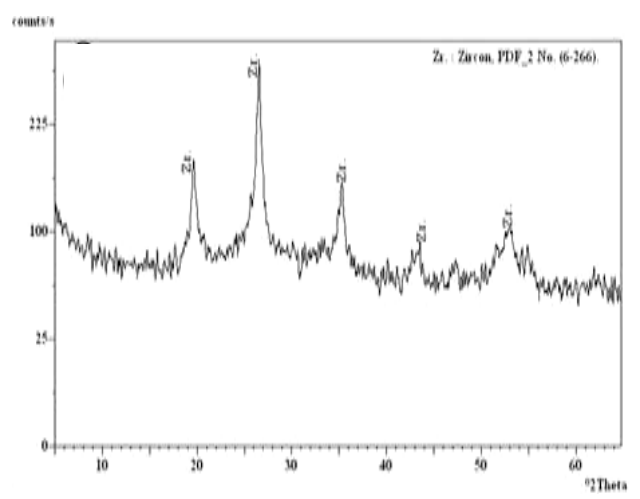

Fig. 25: X-ray diffractogram of zircon 


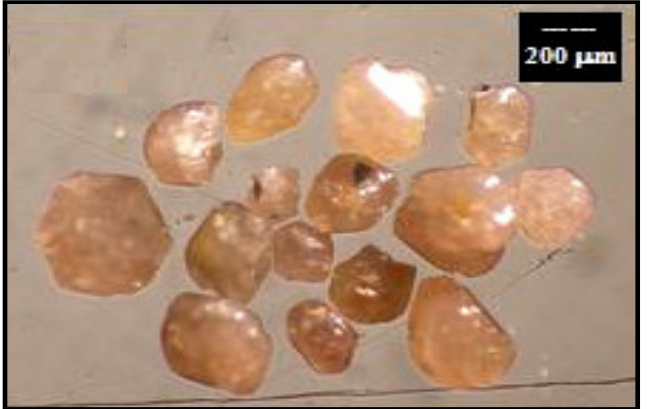

Fig. 26: Photomicrograph of mud zircon

bite and zircon. Monazite crystals are found in appreciable amount, characterized by their relative coarse size. X-ray diffraction pattern of monazite associated with zircon is shown on Figs.27\&28.

\section{Cassiterite $\left(\mathrm{SnO}_{2}\right)$}

It is a tin oxide mineral recorded in studied pegmatites nearly the areas of contact metamorphism and altered zones. It is generally opaque, but it is translucent in thin crystals (Figs. 29\&30). It is a common accessory minerals found is moderately to high evolved assemblages within a pegmatite (Simmons et al., 2003).

\section{Pyrite $\left(\mathrm{FeS}_{2}\right)$}

It is the most common sulfide minerals and usually found associated with other sulfides or oxides in pegmatite veins. The pyrite mineral occurs as isometric crystals that usually appear as cubes (Figs. 31\&32).

\section{Fluorite $\left(\mathrm{CaF}_{2}\right)$}

It is associated with mica varying from colorless to blue or even deep violet (Figs.33\& 34). The studied fluorite is of secondary origin from hydrothermal solution percolating in the pegmatite.

\section{Micas and Opaques}

Both muscovite[K,Na)(Al,Mg,Fe) $\left.\left(\mathrm{Si}_{81} \mathrm{Al}_{9}\right) \mathrm{O}_{10}(\mathrm{OH})_{2}\right]$ and Phlogopite [K Mg Al $\left.\left(\mathrm{SiO}_{4}\right)_{3}\right]$ varieties of mica have been identified in the studied pegmatite. They occur as small flakes, crystal tabular with hexagonal

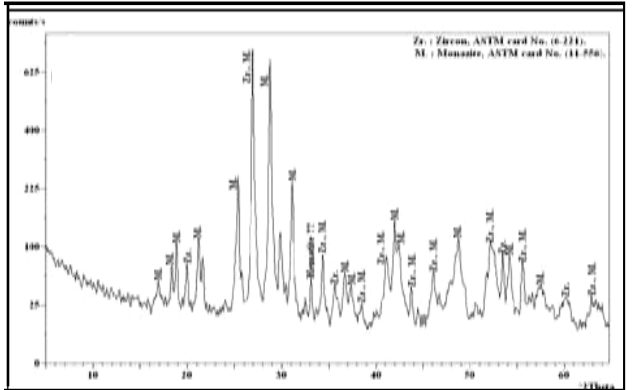

Fig. 27: X-ray diffractogram of zircon and monazite

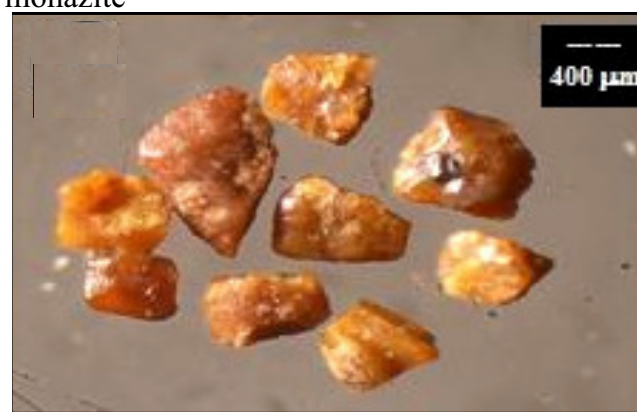

Fig. 28: Photomicrograph of monazite grains

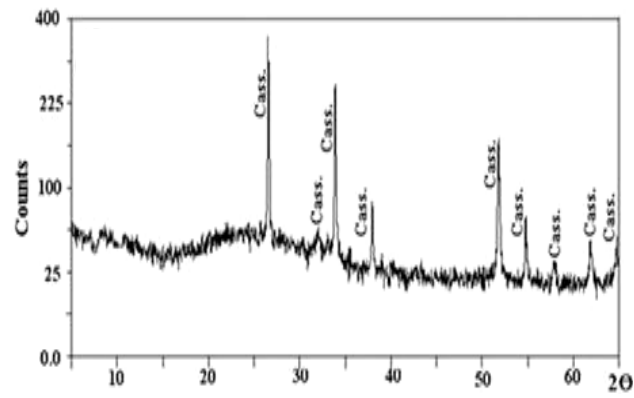

Fig. 29 : X-ray diffractogram of cassiterite

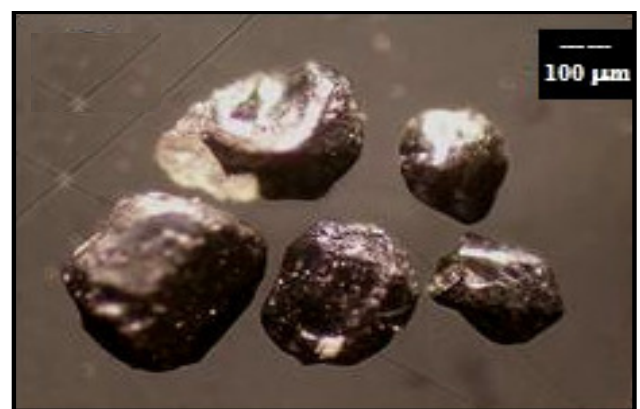

Fig. 30: Photomicrograph of cassiterite grains 


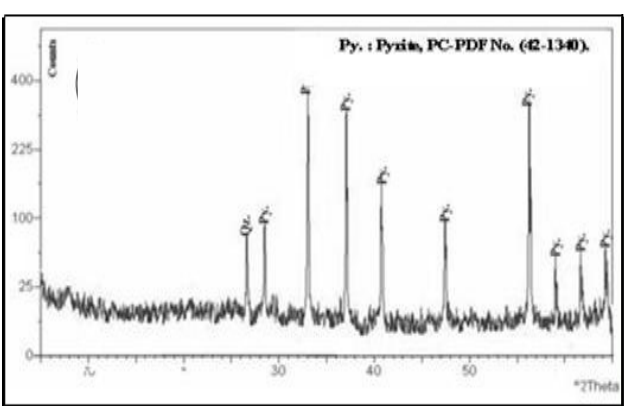

Fig. 31: X-ray diffractogram of pyrite

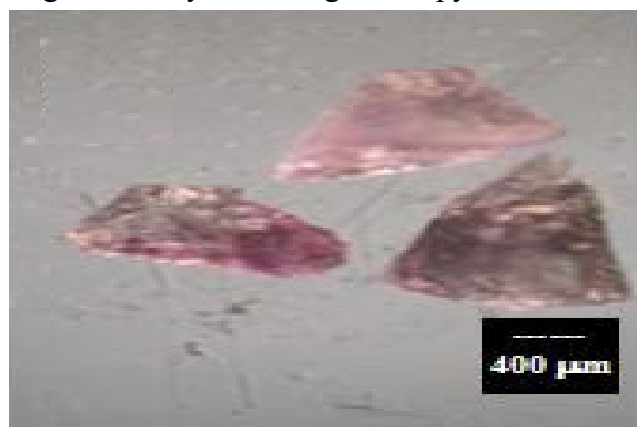

Fig. 32: Photomicrograph of pyrite grains

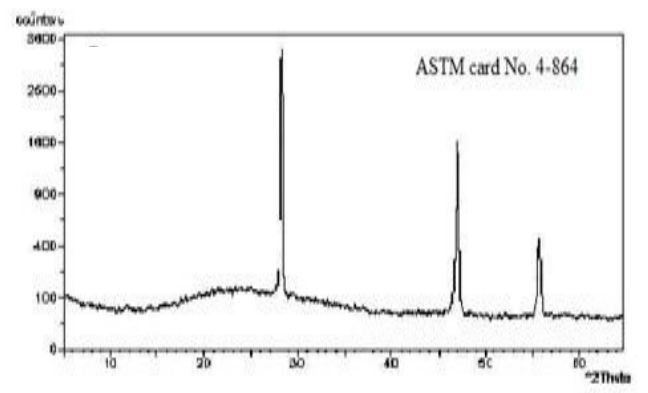

Fig. 33: X-ray diffractogram of fluorite

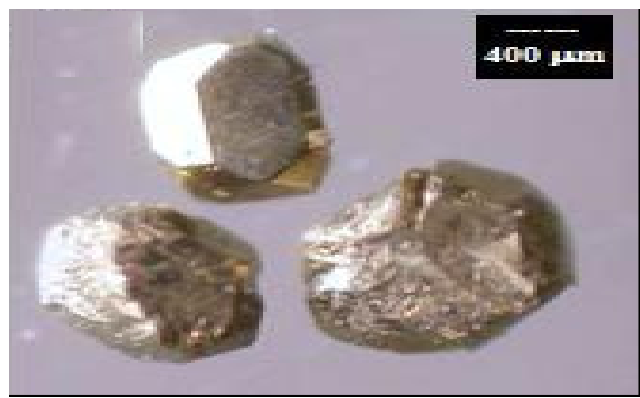

Fig. 34: Photomicrograph of violet fluorite grains outline, colourless or pale-shades of grey or brown in thin sheets with vitreous luster and white streak. X-ray diffraction detected the pattern of muscovite (Fig. 35\&36). Formation of phlogopite could have originated from the parent magmatic biotite which was destroyed at the deuteric-hydrothermal stage, due to the presence of $F$ in the melt. It was converted into fluorine rich phlogopite as fluor-phlogopite. X-ray diffraction analysis detected the phlogopite mineral (Figs. 37\&38).

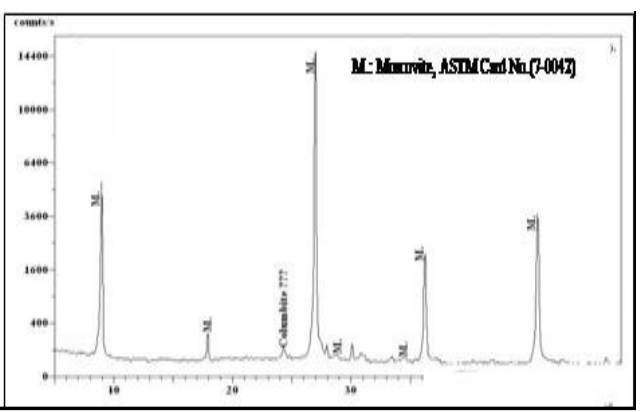

Fig. 35: X-ray diffractogram of muscovite

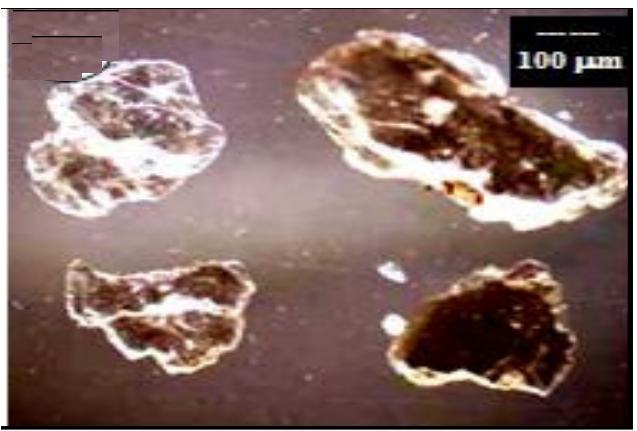

Fig. 36: Flakes from muscovite

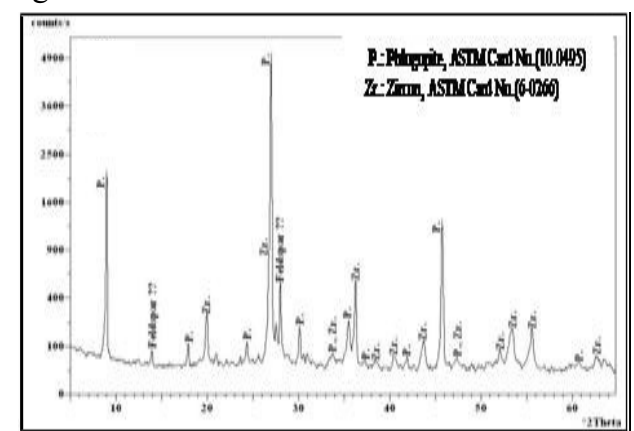

Fig. 37: X-ray diffractogram of phlogopite and zircon 


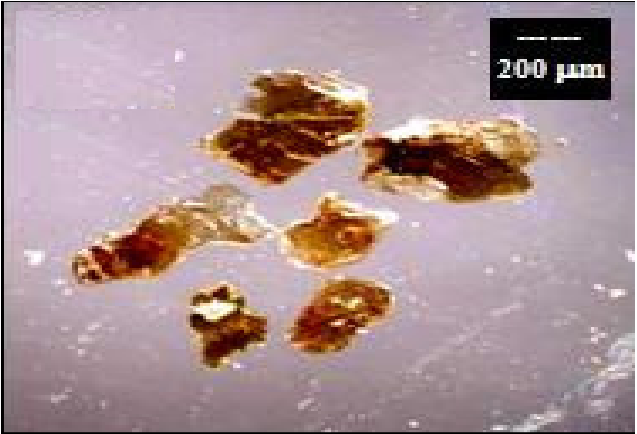

Fig. 38: Photomicrograph showing brown phlogopite mineral

Iron oxides represent the most abundant opaque minerals in the studied pegmatite. These include iron oxides, e.g. hematite $\left(\mathrm{Fe}_{2} \mathrm{O}_{3}\right)$ and goethite $\left(\mathrm{HFeO}_{2}\right)$. Hematite is present as tabular crystals of steel grey to iron black, deep blood red colours. Goethite occurs usually as alteration product of iron-bearing minerals such as pyrite and magnetite. Hematite and some traces from magnetite are also found as by-products of columbite-tantalite minerals alteration in the studied pegmatite. $\mathrm{X}$-ray diffraction pattern of opaque minerals is shown in (Fig. 39).

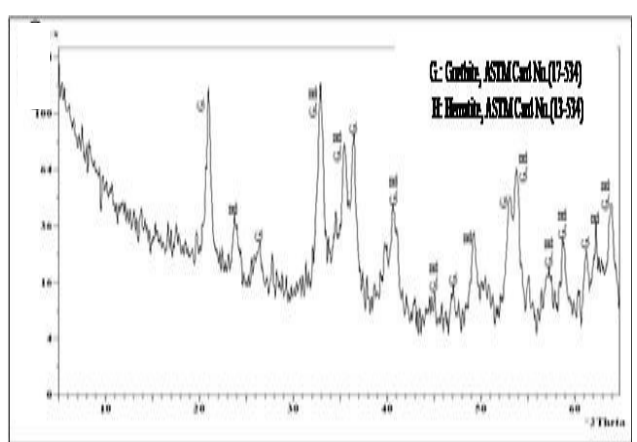

Fig. 39: X-ray diffractogram of goethite and hematite minerals

\section{GEOCHEMISTRY}

\section{Major Oxides and Trace Elements of Pegmatite}

The studied pegmatites are characterized by their high $\mathrm{SiO}_{2}(>74 \%)$ and total alkalis with the average of $9.44 \%$. They have low abundance of $\mathrm{Fe}_{2} \mathrm{O}_{3 \mathrm{t}}(<1.12 \%), \mathrm{MgO}(<1.01)$, $\mathrm{MnO}(<0.07 \%), \mathrm{CaO}(<1.26)$ and $\mathrm{TiO}_{2}(<0.04)$. The $\mathrm{Al}_{2} \mathrm{O}_{3}$ content ranges from $12.12 \%$ to $13.71 \%$ (Table.1). Regarding the trace elements, they are characterized by their high Zr (530 -19980 ppm), Rb (863-2881ppm), Y (245-2277 ppm), Nb (17-879 ppm) as well as

Table 1 : Major oxides (Wt. \%) and trace elements (ppm) of the Khour Abalea pegmatite. SED, Egypt

\begin{tabular}{|c|c|c|c|c|c|c|c|c|c|c|c|c|c|c|c|c|c|}
\hline $\begin{array}{l}\text { Sp. } \\
\text { No. }\end{array}$ & $\mathbf{1}$ & 2 & 3 & 4 & 5 & 6 & 7 & 8 & 9 & 10 & 11 & 12 & 13 & 14 & 15 & 16 & Av \\
\hline \multicolumn{18}{|c|}{$\overline{M a j o r ~ O x i d e s ~(W t ~ \%) ~}$} \\
\hline $\mathrm{SiO}_{2}$ & 74.67 & 76.25 & 75 & 74.04 & 76.27 & 75.35 & 75.35 & 74.51 & 76.75 & 544.17 & 75.1 & $\mathbf{7 4 . 4 8}$ & $\mathbf{7 4 . 8 8}$ & 75.51 & 74.03 & 75.01 & 75.12 \\
\hline $\mathrm{TiO}_{2}$ & o.01 & 0.02 & 0.01 & 0.03 & 0.04 & 0.01 & 0.01 & 0.01 & o. 01 & 0.2 & 0.01 & 0.03 & 0.02 & 0.01 & 0.03 & 0.02 & 0.04 \\
\hline $\mathbf{A l}_{2} \mathbf{O}_{3}$ & 12.12 & 12.16 & 12.48 & 13.90 & 12.9 & 13.93 & 12.93 & 13.05 & 12.41 & 12.85 & 13.11 & 13.71 & 12.96 & 13.10 & 13.61 & 13.1 & 13.08 \\
\hline $\mathrm{Fe}_{2} \mathrm{O}_{3 \mathbf{t}}$ & 0.75 & 0.64 & 0.88 & 0.73 & 0.72 & 0.75 & 0.85 & 1.12 & 1.05 & $5 \quad 0.79$ & 0.88 & 0.96 & 0.88 & 0.56 & 0.48 & 0.68 & 0.80 \\
\hline MnO & 0.07 & 0.04 & 0.02 & 0.04 & 0.06 & 0.02 & 0.02 & 0.03 & 0.01 & 1 0.04 & 0.02 & 0.01 & 0.03 & 0.04 & 0.02 & 0.03 & 0.03 \\
\hline MgO & $\mathbf{0 . 0 8}$ & 0.05 & 0.07 & 0.05 & 0.07 & 0.02 & 0.05 & 1.01 & 0.09 & 0.07 & 0.09 & 0.05 & 0.05 & 0.09 & 0.05 & 0.07 & 0.14 \\
\hline CaO & 0.52 & 0.38 & 0.98 & 0.82 & 0.96 & 0.86 & 0.86 & 0.96 & 0.69 & $\quad 0.99$ & 0.79 & 0.50 & 1.26 & 0.99 & 1.01 & 0.87 & 0.84 \\
\hline $\mathrm{Na}_{2} \mathrm{O}$ & 5.86 & 4.67 & 5.24 & 3.60 & 3.48 & 5.34 & 5.34 & 4.03 & 4.30 & 5.7 & 5.03 & 4.21 & 5.11 & 5.69 & 4.95 & 5.03 & 4.85 \\
\hline $\mathbf{K}_{2} \mathbf{O}$ & 4.88 & 4.94 & 3.32 & 5.81 & 4.78 & 4.2 & 4.20 & 4.79 & 3.95 & 4.48 & 4.6 & 4.59 & 4.64 & 4.29 & 5.28 & 4.7 & 4.59 \\
\hline $\mathbf{P}_{2} \mathbf{O}_{5}$ & 0.01 & 0.02 & 0.00 & 0.01 & 0.02 & 0.01 & o.01 & 0.02 & o.01 & 0.01 & 0.09 & 0.06 & 0.02 & 0.02 & 0.03 & 0.02 & 0.02 \\
\hline L.O.I & 0.23 & 0.50 & 0.0.19 & 0.22 & 0.21 & 0.28 & 0.28 & 0.26 & 0.29 & 0.32 & 0.45 & 0.55 & 0.58 & 0.49 & 0.38 & 0.5 & 0.34 \\
\hline Total & 99.20 & 99.67 & 99.50 & 99.25 & 99.51 & 00.77 & 99.90 & 99.79 & 99.55 & 99.62 & 00.17 & 99.15 & 00.43 & 00.97 & 99.87 & Do.03 & 99. \\
\hline \multicolumn{18}{|c|}{ Trace Elements (ppm) } \\
\hline $\mathrm{Cr}$ & 91 & 82 & 79 & 87 & 87 & 68 & 60 & 87 & 87 & 66 & 91 & 59 & 92 & 90 & 8 & 75 & 80 \\
\hline Ni & 11 & 10 & 12 & 14 & 3 & 10 & 3 & 12 & 4 & 10 & & 9 & & & & 8 & \\
\hline $\mathbf{C u}$ & 15 & 10 & 15 & 12 & 13 & 13 & 8 & 11 & 9 & 10 & 2 & 2 & 18 & 10 & , & & 11 \\
\hline Zn & 341 & 250 & 367 & 685 & 695 & 512 & 326 & 889 & 777 & 234 & 243 & 341 & 1056 & 264 & 331 & 442 & 485 \\
\hline 7 & 1931 & 1998 & 1021 & 1246 & & 1731 & 985 & 839 & 826 & & & & & 1998 & 10 & 1246 & 1214 \\
\hline Rb & 2881 & 2789 & 1753 & 1528 & 863 & 2300 & 1541 & 1274 & 1441 & 1499 & 911 & 884 & 2881 & 2789 & 1753 & 1528 & 1788 \\
\hline $\mathbf{Y}$ & 2277 & 1849 & 1860 & 581 & 893 & 801 & 2244 & 856 & 1909 & 1832 & 1558 & 2490 & 245 & 687 & 523 & 689 & 1330 \\
\hline B & 35 & 25 & 28 & & 17 & 18 & 30 & 33 & 29 & & 2 & & & & & 15 & 24 \\
\hline Pb & 94 & 88 & 33 & 76 & 53 & 75 & 32 & 90 & 98 & 59 & 45 & 55 & 40 & 76 & 60 & 49 & 64 \\
\hline$S_{1}$ & 292 & 235 & 237 & 66 & 105 & 95 & 282 & 103 & 239 & 231 & 195 & 315 & 21 & & & 78 & 164 \\
\hline & 15 & 19 & 14 & 1 & 11 & 11 & 13 & 15 & 13 & 12 & 9 & 2 & 10 & 11 & 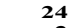 & 10 & 14 \\
\hline $\mathbf{V}$ & 2 & 2 & 2 & 3 & 2 & 3 & 2 & 2 & 2 & 4 & 3 & 2 & 2 & 2 & 2 & 3 & \\
\hline NI & 879 & 712 & 717 & 217 & 336 & 302 & 864 & 324 & 735 & 705 & 17 & 958 & 8 & 244 & 186 & 249 & 471 \\
\hline H & 28 & 21 & 28 & 2 & 20 & 32 & 34 & 26 & 25 & 2 & & 1 & 1 & & 2 & 34 & \\
\hline$\underline{\text { Ta }}$ & 32 & 26 & 14 & 12 & 11 & 19 & 26 & 23 & 19 & 18 & 14 & 12 & 20 & 18 & 11 & 16 & 18 \\
\hline
\end{tabular}


Ta with average of $18 \mathrm{ppm}$ and $\mathrm{Pb}$ with average of $64 \mathrm{ppm}$. They are depleted in, $\mathrm{Cu}, \mathrm{Ni}$, $\mathrm{Ga}, \mathrm{V}$ and $\mathrm{Ba}$. The variation in most elements especially $\mathrm{Si}, \mathrm{Na}, \mathrm{K}, \mathrm{Nb}, \mathrm{Ta}$, and $\mathrm{Pb}$ can be attributed to the alteration processes especially the Na-metasomatism that caused albitization and desilicafication of the studied pegmatites.

In correlation between major oxides of the studied pegmatite and the hosted rocks representing by the cataclastic rocks (mylonite rock) according to Rashed (2005), It can be noted that the studied pegmatite more rich in $\mathrm{SiO}_{2}$ and $\mathrm{K}_{2} \mathrm{O}$ related to hosted rock (mylonitic rocks) It is also depleted in $\mathrm{Al}_{2} \mathrm{O}_{3}, \mathrm{TiO}_{2}, \mathrm{Fe}_{2} \mathrm{O}_{3}$, $\mathrm{MgO}, \mathrm{MnO}, \mathrm{CaO}, \mathrm{P}_{2} \mathrm{O}_{5}$ and $\mathrm{Na}_{2} \mathrm{O}$ (Fig.40a).

Regarding to trace elements, It can be noted that the pegmatite under study is rich in $\mathrm{Rb}$ , $\mathrm{Sr}$ and $\mathrm{Y}$ related to hosted rock as well as depleted in $\mathrm{Cu}, \mathrm{Zn}, \mathrm{Zr}, \mathrm{Ba}, \mathrm{Pb}, \mathrm{Ga}, \mathrm{V}, \mathrm{Nb}, \mathrm{Hf}$, and Ta (Fig.40b).

The studied pegmatites are calc-alkaline and peraluminous (Figs. 41\&42 ) where
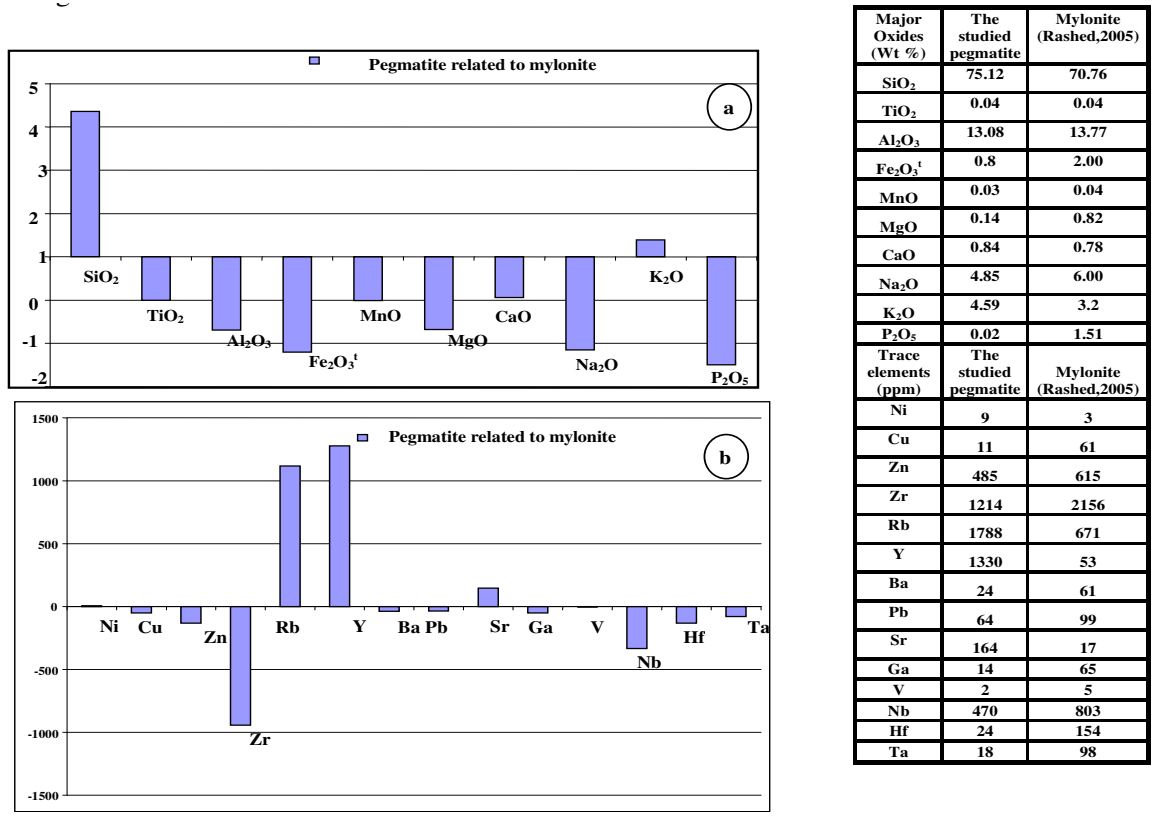

Fig. $40 \mathrm{a} \& \mathrm{~b}$ : The enrichment and depletion diagram in major oxides and trace elements of the studied pegmatite according to hosted rock (After Rashed, 2005)
$\mathrm{Al}_{2} \mathrm{O}_{3}>\left(\mathrm{CaO}+\mathrm{Na}_{2} \mathrm{O}+\mathrm{K}_{2} \mathrm{O}\right)$. Khour Abalea pegmatite is collectively of the S-type (Fig.43), exhibiting their sedimentary origin and show high $\mathrm{Rb}$ and low $\mathrm{Sr}$ contents under the control of the fractional crystallization (Fig. 44). Sr is concentrated by plagioclases in early stages, whereas $\mathrm{Rb}$ is incompatible element and remains in the melt and increases progressively with crystallization, (Harris and Inger, 1992). $\mathrm{The} \mathrm{Rb} / \mathrm{Sr}$ ratio is an important criterion to distinguish between magma coming from the upper crust $(\mathrm{Rb} / \mathrm{Sr}=0.25)$ and lower crust $(\mathrm{Rb} /$ $\mathrm{Sr}=0.02-0.04) \quad$ (Schroll, 1976). The studied pegmatites have $\mathrm{Rb} / \mathrm{Sr}$ ratio vary from 6.03 to 59.24 suggesting crustal contamination during the rise of the magma.

On the $\mathrm{Ba} / \mathrm{Rb}$ diagram (Fig.45) all the date points are plotted in the field where $\mathrm{Rb} / \mathrm{Ba}$ ratio equal to $4.4 * 10^{-2}$. Hence the characteristically low $\mathrm{Ba} / \mathrm{Rb}$ ratios of the studied pegmatites are a reflection of its chemical specialization or its potential for mineralization.

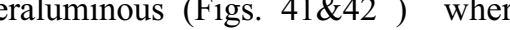




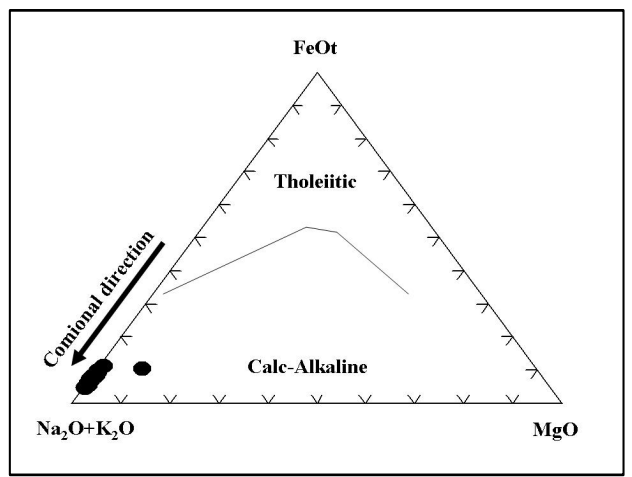

Fig.41: AFM diagram (Irvine and Baragar, 1971) Tensional trend (After Petro et al., 1979)

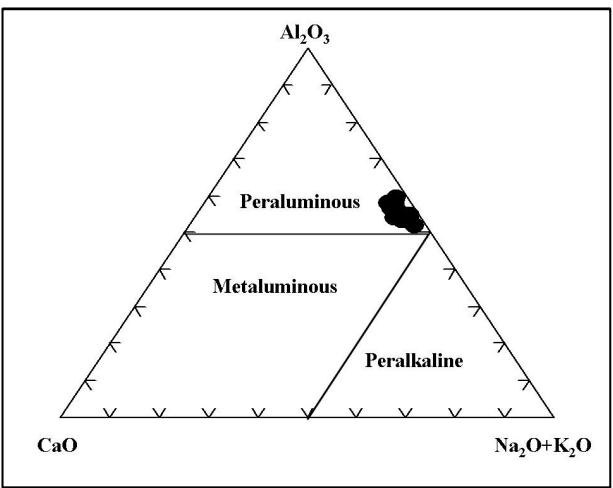

Fig. 42: $\mathrm{Al}_{2} \mathrm{O}_{3}-\mathrm{CaO}-\left(\mathrm{Na}_{2} \mathrm{O}+\mathrm{K}_{2} \mathrm{O}\right)$ diagram (After Shand, 1951)

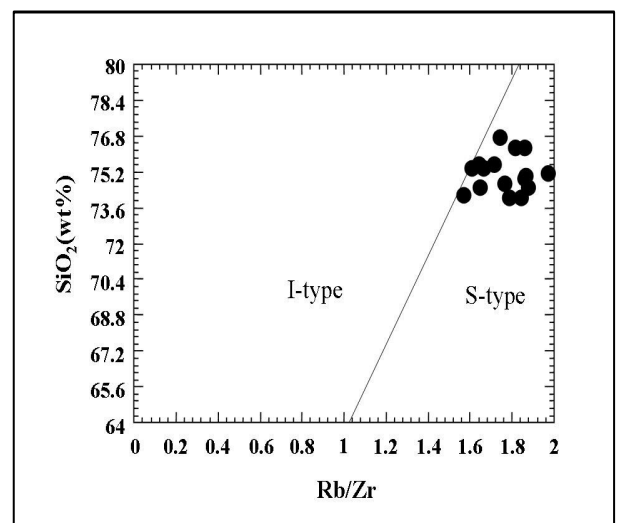

Fig. 43: $\mathrm{Rb} / \mathrm{Zr}$ vs. $\mathrm{SiO}_{2}$ diagram (Fields of I and $\mathrm{S}$ granites after Harris et al. (1984)

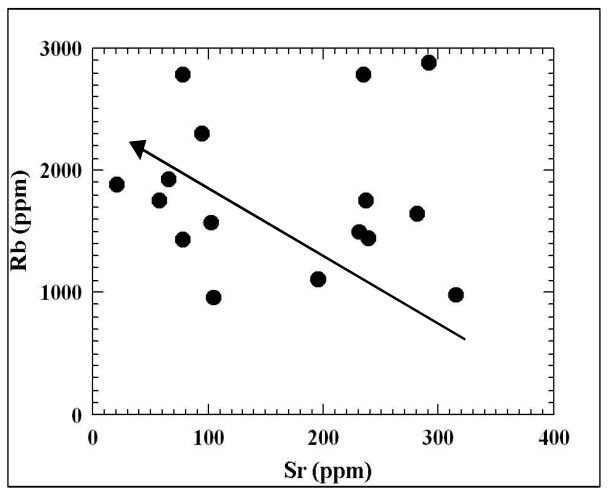

Fig. 44: Rb-Sr variation diagram

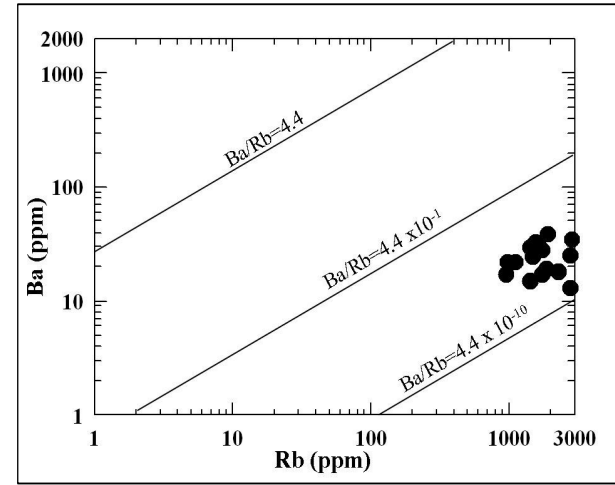

Fig. 45: $\mathrm{Ba}-\mathrm{Rb}$ variation diagram (After Mason, 1966)

\section{Alteration Features}

The weathering trends are displayed on $\left(\mathrm{CaO}+\mathrm{Na}_{2} \mathrm{O}\right)-\mathrm{Al}_{2} \mathrm{O}_{3}-\mathrm{K}_{2} \mathrm{O}$ triangular diagram after (Nesbitt and Young, 1984 and 1989). Pegmatite samples fall in the trend of alteration $\mathrm{d}$ showing a relative depletion in $\mathrm{K}_{2} \mathrm{O}$ and $\mathrm{CaO}+\mathrm{Na}_{2} \mathrm{O}$ compositions (Fig.46). This may be due to the relative alteration of feldspars to clay minerals.

AKF ternary diagram after (Meyer and Hemley 1967) shows that all samples of pegmatite under study fall closed to sericite field beside A-K line (Fig.47). This may be attributed to their high contents of $\mathrm{Al}_{2} \mathrm{O}_{3}+\mathrm{FeO}$, where $\mathrm{Al}_{2} \mathrm{O}_{3}$ is related to clay minerals, while $\mathrm{FeO}$ is related to the ferrugination process. 


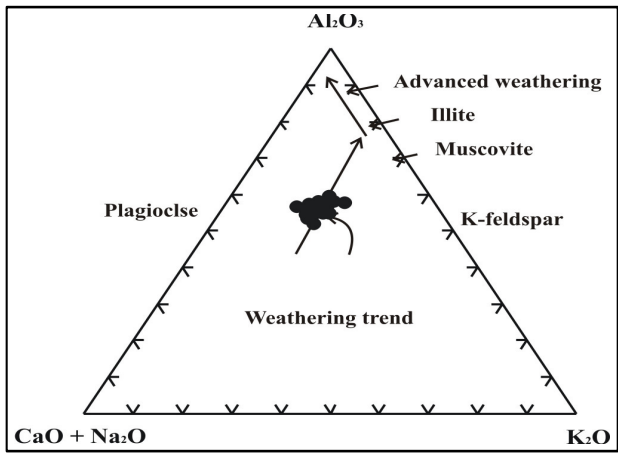

Fig. 46: $\mathrm{Al}_{2} \mathrm{O}_{3}-\left(\mathrm{CaO}+\mathrm{Na}_{2} \mathrm{O}\right)-\mathrm{K}_{2} \mathrm{O}$ ternary diagram (After Nesbitt and Young, 1984 and 1989)

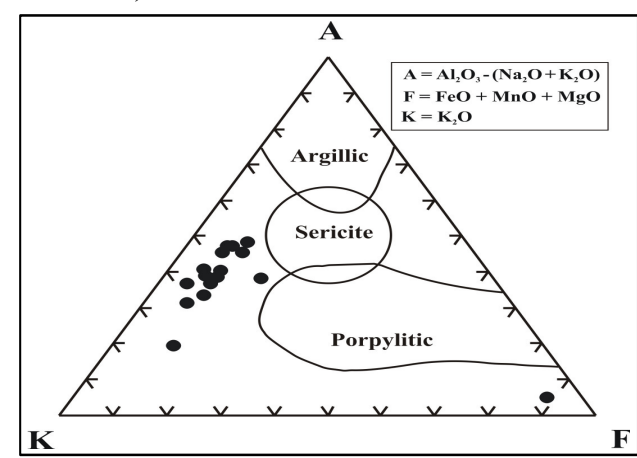

Fig. 47: AKF ternary diagram (After Meyer and Hemley, 1967)

Also, the pegmatite samples plotted on the $\mathrm{Na}-\mathrm{K}$ variations diagram according to Cuney et al., 1989 lie between Na-K metasomatism toward the desilicafication field (Fig.48) because after the Na- and K-metasomatism, the $\mathrm{H}+$ metasomatism (hydrolysis) is followed and characterized by formation of sericite (sericitization) being accompanied by the release of quartz (desilicification).

The pegmatite are fairly similar to the continental crust (Taylor and Mclennan, 1985) with respect to $\mathrm{Rb}, \mathrm{Nb}, \mathrm{Ba}, \mathrm{Sr}, \mathrm{Ni}, \mathrm{Cu}, \mathrm{Zn}$ and $\mathrm{Ga}$ (Fig.49) suggesting either derivation from crustal materials with nearly the same composition and/or that crustal contamination has played the major role in the generation of these pegmatite.

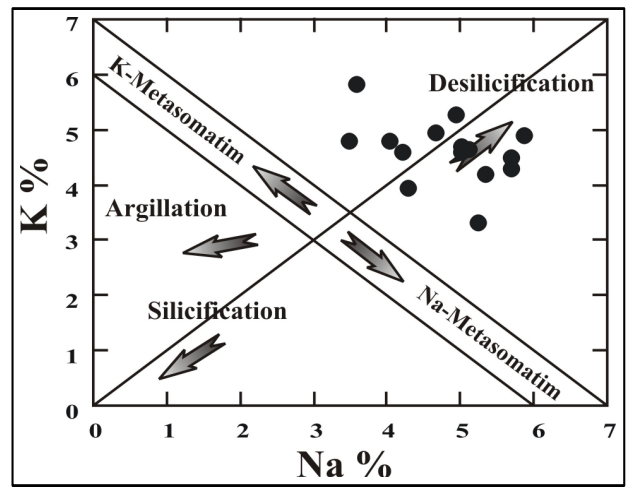

Fig. 48: $\mathrm{Na} \%-\mathrm{K} \%$ variation diagram, showing the alteration type (After Cuney et al., 1989)

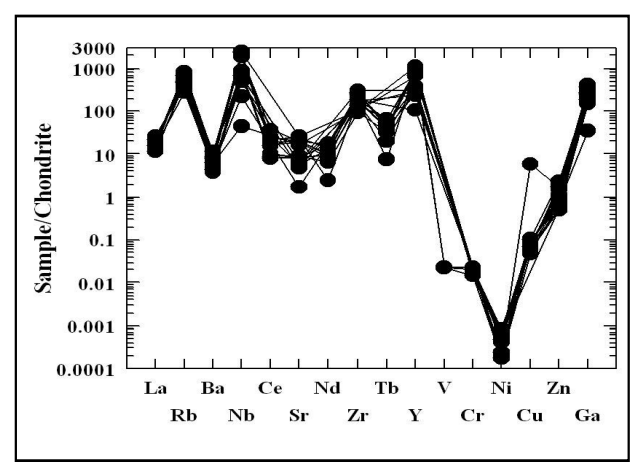

Fig.49: Spider diagram of Khour Abalea pegmatite (Taylor and Mclennan, 1985)

\section{Geochemistry of the Isovalents}

The mutual abundance and distribution of the isovalents (e.g., Zr-Hf, Nb-Ta and YHo) in most geological environments follow the popularly known Goldschmidt's rule (i-e, charge and radius control, CHARAC). Bau et al. (1995) and Bau (1996, 1999) should be mentioned these isovalent may be strongly fractionated by pegmatite-forming processes. The fractionation takes places either through depletion or enrichment of the heaver isovalents relative to the lighter ones. The non-differentiated ratios of the isovalent are; 35, 17, 28 for $\mathrm{Zr} / \mathrm{Hf}, \mathrm{Nb} / \mathrm{Ta}$ and $\mathrm{Y} / \mathrm{Ho}$ respectively (Weyer et al., 2002).

The $\mathrm{Zr} / \mathrm{Hf}$ ratio in the studied pegmatite ranges between 26.50 and 95.14 (Table.3) 
being above CHARAC field $(26<\mathrm{Zr} / \mathrm{Hf}<46)$ (Bau, 1996). The $\mathrm{Zr} / \mathrm{Hf}$ ratio suggests significant change in the crystal chemistry of zircon towards increasing contents of Hf. such fractionation may take place during alkali metasomatic alteration which lead to enrichment of the earth alkalis such as $\mathrm{Ca}$ and $\mathrm{Sr}$ in addition to $\mathrm{Na}$ according to Takahashi et al. (2002).

$\mathrm{The} \mathrm{Nb} / \mathrm{Ta}$ fractionation is generally well developed in $\mathrm{Nb}$ and $\mathrm{Ta}$ oxide minerals from rare element $\mathrm{Li}$ bearing pegmatites (e.g. Černý and Ercit 1989; Linnen 1998) and also in some REE-enriched pegmatites (Ercit, 2005). Nb/Ta ratio varies between 14.09 and 51.21 (Table.2) which is above the chondritic ratio refer to the critical increase in the $\mathrm{Nb}$ related to $\mathrm{Ta}$ due to effect of hydrothermal solution. Magmatic rocks of continental crust origin generally have low $\mathrm{Nb} / \mathrm{Ta}$ ratio (11-12) (Wades and Wood, 2001) and the chondritic ratio $\mathrm{Nb} / \mathrm{Ta}$ is 17.6 according to Weyer et al., (2002).

The $\mathrm{Y} / \mathrm{Ho}$ ratio ranges from 83.44 to 690.46 (Table.2), which is higher than CHAR$\mathrm{AC}$ (the chondritic ratio of $\mathrm{Y} / \mathrm{Ho}$ is 28 (Weyer et al., op.cit). Bau and Dulski (1995) suggest the complexation with fluorine as major cause for values $>28$, while the complexing with bicarbonate is assumed to generate values $<28$. The mineralogical examination indicates the presence of fluorite in the studied pegmatite.

From the above geochemical behavior of the three isovalents, it can be assumed the influence of fluorine-rich hydrothermal solutions. The distinct behavior of the isovalent ratios $(\mathrm{Zr} / \mathrm{Hf}, \mathrm{Nb} / \mathrm{Ta}$ and $\mathrm{Y} / \mathrm{Ho})$ during alterations seems to be non-chondritic and is no longer exclusive to the control of ionic radius and charge and also, refers to high fractionation due to high hydrothermal alteration processes.

\section{REEs Geochemistry}

The total REEs content in the pegmatite ranges from 95.71 to $204.13 \mathrm{ppm}$ with LREE/HREE ratio ranges from 0.31 to 0.71 (Table.2). Pegmatite have clear negative $\mathrm{Eu}$
Table 2: Results of REEs (ppm) and some parameters of pegmatite of Khour Abalea, South Eastern Desert, Egypt

\begin{tabular}{|c|c|c|c|c|c|c|c|c|c|c|}
\hline Sp. $\mathrm{N}_{0}$. & 1 & 4 & 5 & 6 & 7 & 8 & 9 & 10 & 11 & 12 \\
\hline $\mathrm{La}$ & 6.90 & 5.10 & 9.20 & 7.75 & 5.82 & 6.67 & 4.20 & 4.65 & 8.15 & 9.56 \\
\hline $\mathrm{Ce}$ & 22.54 & 17.70 & 35.32 & 25.20 & 7.55 & 7.96 & 14.90 & 9.65 & 22.95 & 15.73 \\
\hline Pr & 3.60 & 2.90 & 5.70 & 2.90 & 1.22 & 4.30 & 1.60 & 1.15 & 2.55 & 2.75 \\
\hline $\mathrm{Nd}$ & 9.70 & 7.32 & 12.00 & 9.50 & 4.65 & 12.35 & 1.75 & 6.66 & 6.95 & 6.23 \\
\hline $\mathrm{Sm}$ & 4.20 & 3.20 & 9.60 & 12.30 & 6.60 & 11.25 & 0.86 & 10.90 & 13.12 & 12.75 \\
\hline Eu & 0.10 & 0.11 & 0.10 & 0.10 & 0.10 & 0.80 & 0.10 & 0.10 & 0.10 & 0.10 \\
\hline $\mathrm{Gd}$ & 4.20 & 3.80 & 11.45 & 7.60 & 2.80 & 10.35 & 0.86 & 9.15 & 6.35 & 5.75 \\
\hline $\mathrm{Tb}$ & 2.60 & 2.42 & 3.75 & 2.40 & 1.92 & 3.20 & 0.45 & 1.15 & 3.70 & 2.26 \\
\hline Dy & 19.85 & 13.50 & 17.65 & 13.40 & 12.70 & 22.66 & 6.40 & 10.15 & 16.15 & 13.85 \\
\hline $\mathrm{H}_{0}$ & 6.12 & 4.52 & 11.77 & 5.35 & 6.40 & 9.60 & 3.25 & 7.75 & 8.73 & 6.25 \\
\hline Er & 20.25 & 13.85 & 26.25 & 17.20 & 14.20 & 28.60 & 15.33 & 21.15 & 24.95 & 13.96 \\
\hline $\mathrm{Tm}$ & 4.70 & 2.75 & 12.40 & 7.30 & 5.15 & 10.02 & 12.15 & 12.40 & 15.95 & 12.85 \\
\hline $\mathrm{Yb}$ & 40.30 & 27.40 & 36.49 & 23.50 & 23.45 & 31.60 & 35.75 & 20.55 & 25.80 & 24.45 \\
\hline Lu & 8.23 & 5.10 & 12.45 & 4.65 & 3.15 & 5.00 & 2.22 & 4.10 & 6.45 & 6.55 \\
\hline ¿REE & 153.29 & 109.67 & 204.13 & 139.15 & 95.71 & 164.36 & 99.82 & 119.51 & 161.9 & 133.04 \\
\hline ¿LREE & 46.94 & 36.22 & 71.825 & & 25.84 & 42.53 & 23.31 & 33.01 & 53.72 & 47.02 \\
\hline ¿HREE & 106.25 & 73.34 & 132.21 & 81.4 & 69.77 & 121.03 & 76.41 & 86.4 & 108.08 & 85.92 \\
\hline ¿LREE/ ¿HREE & 0.44 & 0.49 & 0.54 & 0.71 & 0.37 & 0.35 & 0.31 & 0.38 & 0.50 & 0.55 \\
\hline $\mathrm{Ce} / \mathrm{Ce}^{*}$ & 1.39 & 1.47 & 1.68 & 1.45 & 0.67 & 0.47 & 2.27 & 0.88 & 1.42 & 0.91 \\
\hline $\mathrm{Eu} / \mathrm{Eu}^{*}$ & 0.07 & 0.10 & 0.03 & 0.03 & 0.07 & 0.23 & 0.36 & 0.03 & 0.03 & 0.04 \\
\hline$t_{1}$ & 1.51 & 1.61 & 1.86 & 1.37 & 0.80 & 0.89 & 2.47 & 0.82 & 1.40 & 1.17 \\
\hline$t_{3}$ & 1.56 & 1.52 & 0.77 & 0.98 & 1.29 & 0.94 & 1.12 & 0.45 & 1.15 & 1.03 \\
\hline$t_{13}$ & 1.54 & 1.57 & 1.20 & 1.16 & 1.02 & 0.91 & 1.67 & 0.61 & 1.27 & 1.10 \\
\hline $\mathrm{K}_{2} \mathrm{O} / \mathrm{Na}_{2} \mathrm{O}$ & 0.83 & 1.06 & 0.63 & 1.61 & 1.37 & 0.79 & 0.79 & 1.19 & 0.92 & 0.79 \\
\hline $\mathrm{Rb} / \mathrm{Sr}$ & 9.87 & 11.87 & 7.40 & 23.15 & 8.22 & 24.21 & 5.46 & 12.37 & 6.03 & 6.49 \\
\hline $\mathrm{K} / \mathrm{Rb}$ & 14.06 & 14.70 & 15.97 & 31.54 & 45.89 & 15.17 & 22.65 & 31.24 & 22.76 & 24.82 \\
\hline $\mathrm{Nb} / \mathrm{Ta}$ & 27.47 & 27.38 & 51.21 & 18.08 & 30.55 & 15.89 & 33.23 & 14.09 & 38.68 & 39.17 \\
\hline $\mathrm{Zr} / \mathrm{Hf}$ & 68.96 & 95.14 & 36.46 & 56.64 & 26.50 & 54.09 & 28.97 & 32.27 & 33.04 & 47.70 \\
\hline $\mathrm{Sr} / \mathrm{Eu}$ & 2920 & 2136 & 2570 & 660 & 1050 & 119 & 2820 & 1030 & 2390 & 2310 \\
\hline $\mathrm{Y} / \mathrm{H}_{0}$ & 372.06 & 409,07 & 158.03 & 108.60 & 139.53 & 83.44 & 690.46 & 110.45 & 218.67 & 293.12 \\
\hline
\end{tabular}

anomalies, with $\mathrm{Eu} / \mathrm{Eu}^{*} 0.03-0.36$ (Fig.50), a marked negative Eu anomalies attributed to the break down of their feldspars. Chondritenormalized REE patterns display enrichment of HREE relative to LREE as indicating by the presence of zircon, xenotime and samarskite. 


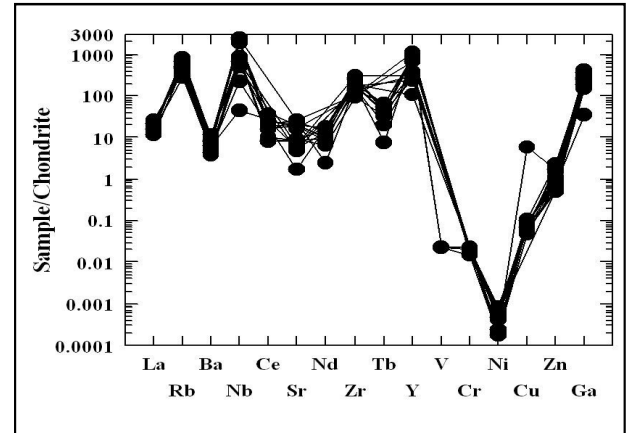

Fig. 50: Chondrite - normalized REE pattern of pegmatite, chondrite values are taken from Anders and Grevesse (1989)

Also, the presence of positive Ce anomaly $\left(\mathrm{Ce} / \mathrm{Ce}^{*}\right)$ ranging from 0.47 to 2.27 is mainly attributed to occurrence of Ce-monazite and to oxidizing conditions. The positive relationship between the total $\sum$ REE and the $\sum$ LREE/ HREE ratio as well as the first tetrad and third (Figs.51\&52) indicates that REEs make financial arrangements especially by the light ones. This can be attributed to the fluxing nature for both $\mathrm{Na}$ and fluorine-rich solutions which may weaken (metamictize) the structure of the HREEs hosting minerals like zircon and xenotime and promoting HREE re-concentration (Bowden, 1974). Rare earth elements of the studied pegmatite rocks from Khour Abalea reveal that the rare earth elements (REEs) are potentially mobile during hydrothermal alteration trivalent where REEs are removed during $\mathrm{K}$ and $\mathrm{Na}$-silicate alteration and $\mathrm{Eu}$ was lost during sericitization.

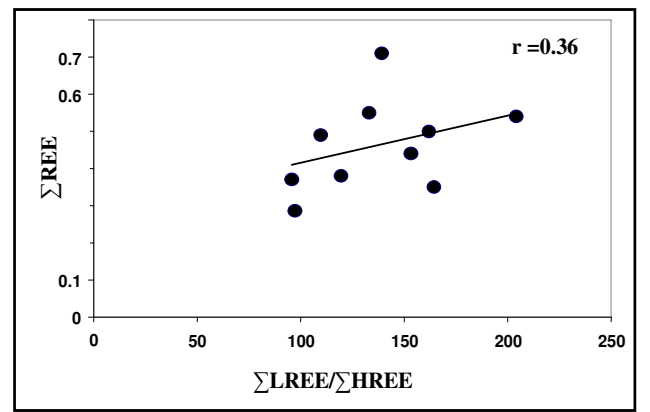

Fig. 51: Binary diagram between LREE / HREE and total REE

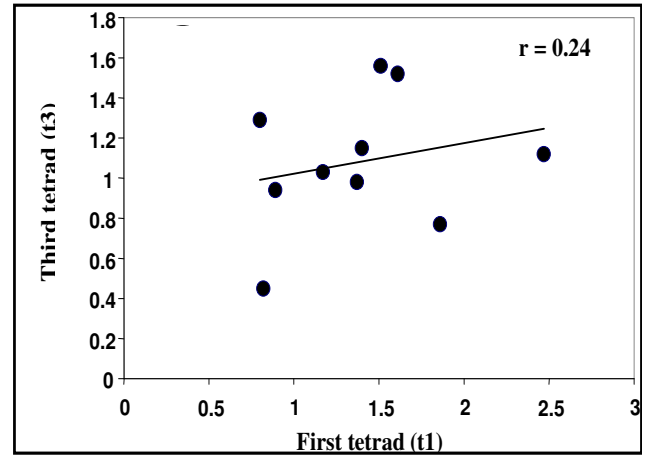

Fig. 52: Binary diagram between first tetrad and third Tetrad

\section{The Lanthanide Tetrad Effect}

The tetrad effect is well recognized in chemistry as affecting the REE complexing behavior, which is assumed to be influenced by variation in the exchange interactions of unpaired 4f-electrons, spin-orbit coupling or crystal field stabilization (Masuda et al., 1987). This effect can cause a spilt of chondrite normalized REE patterns into four rounded segments 1) $\mathrm{La}$ to $\mathrm{Nd}, 2$ ) (Pm) Sm to Gd 3) Gd to Ho and 4) Er to Lu. The segments are either convex or concave and form $\mathrm{M}$ and $\mathrm{W}$-shaped lanthanide distribution patterns, respectively (Masuda et al., op.cit). Recent discussions about the tetrad effect focus on highly evolved igneous rocks being often interpreted as transitional between he endmembers of magmatic and high-temperature hydrothermal systems (Bau,1996).

The geochemical distribution of REE in the present samples has been studied extensively, where they provide a range of geochemical indicators that can be used to constrain the evolution of hydrothermal systems. The pronounced feature that potentially influences the distribution of the REEs in most studied samples is the obvious lanthanide tetrad effect in all individual tetrad segments (Table.2) and Fig (50). The tetrad effect has progressively recognized particularly for the pegmatite which have undergone high degree of fractional crystallization, hydrothermal al- 
teration and mineralization (Zho et al.,1993: Bau, 1996 and Irber et al., 1999)

The chondrite-normalized REE patterns of the studied pegmatite (Fig.50) here show convex (M-type >1.10) pattern called tetrad effect due to the high temperature fluid/rock interaction causing a selective leaching of some REE (Irber, op.cit and Monecke et al., 2002). The calculated tetrad effect in the pegmatite of Khour Abalea demonstrates clear tendency towards the ratios of the common geochemical parameters such as $\mathrm{K} / \mathrm{Rb}, \mathrm{Y} / \mathrm{Ho}$, $\mathrm{Zr} / \mathrm{Hf}, \mathrm{Nb} / \mathrm{Ta}, \mathrm{NaO}_{2}$ and $\mathrm{Sr} / \mathrm{Rb}$ (Figs.53-56, e and $\mathrm{f}$ ). The fractionation of elements which are similar to each other in terms of ionic radius and charge is regarded to be sensitive to changes in melt composition during magma differentiation (Irber et al., 1997).

In Khour Abalea pegmatite, the $\mathrm{K} / \mathrm{Rb}$ ranges from 14.06 to 45.89 and the tetrad effect negatively correlates with $\mathrm{K} / \mathrm{Rb}$ (Fig.53). Shaw (1968) explained the extremely low ratios of $\mathrm{k} / \mathrm{Rb}(<50)$ in pegmatitic-hydrothermal systems by assuming the fractionation between a silicate melt and either biotite or an aqueous phase. Ratios $>100$ are regarded to indicate the interaction with am aqueous fluid phase (Clarke, 1992) or mineral growth in presence of aqueous fluid (Shearer et al., 1985).

The $\mathrm{Y} / \mathrm{Ho}$ ratio ranges from 83.44 to 690.46 (Table.2), which is higher than CHAR$\mathrm{AC}$ (the chondritic ratio of $\mathrm{Y} / \mathrm{Ho}$ is 28 (Weyer et al., 2002). Paralleled by increasing degree of the tetrad effect the ratios shift to values $>$ 28 (Fig.54). The peraluminous S-type pegmatite shift to $\mathrm{Y} / \mathrm{Ho}$ ratios $>28$ (Irber, 1999).

The plot of $\mathrm{Zr} / \mathrm{Hf}$ vs. the tetrad effect shows a positive correlation display significant tetrad effects (Fig.55). The average of pegmatites is about 25 (Erlank et al., 1978) and $\mathrm{Zr} / \mathrm{Hf}$ ratios shift toward smaller ratios with increasing evolution of the silicate melt. Extraordinary high $\mathrm{Zr} / \mathrm{Hf}$ up to 87 in magmatic systems is reported from Dupuy et al., (1992) related to action of $\mathrm{CO}_{2}$ - rich fluids.

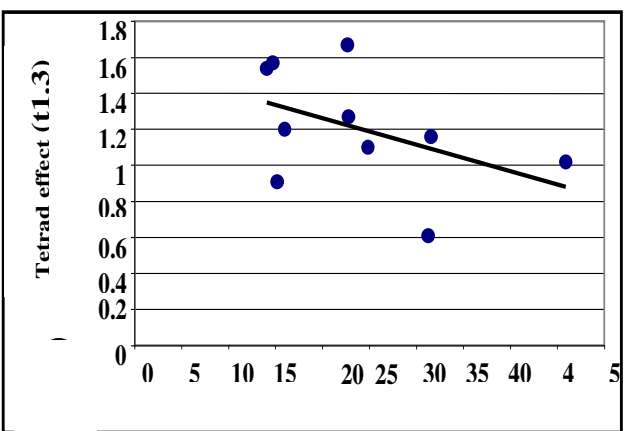

Fig. 53: Tetrad effect vs. K/Rb

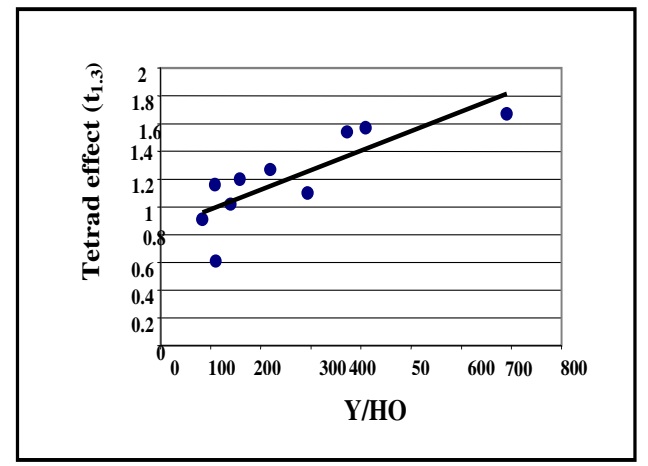

Fig. 54: Tetrad effect vs. Y/Ho

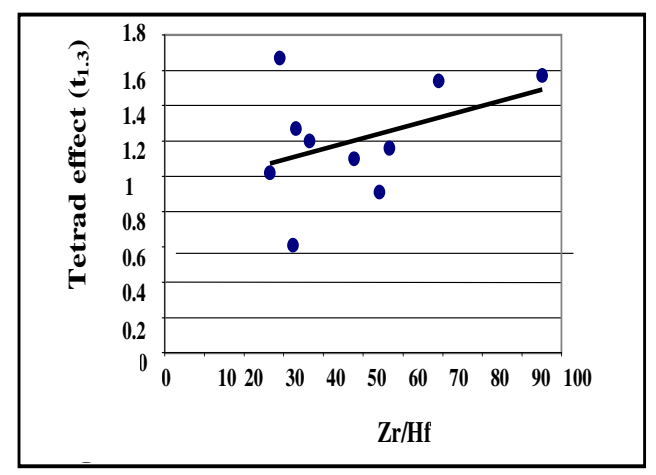

Fig. 55: Tetrad effect vs. $\mathrm{Zr} / \mathrm{Hf}$

$\mathrm{Nb} / \mathrm{Ta}$ ratio varies between 14.09 and 51.21 (Table.2) which is above the chondritic ratio refer to the critical increase in the $\mathrm{Nb}$ related to Ta due to effect of hydrothermal solution. Magmatic rocks of continental crust origin generally have low $\mathrm{Nb} / \mathrm{Ta}$ ratio (11-12) (Wades and Wood, 2001) and the chondritic 
ratio $\mathrm{Nb} / \mathrm{Ta}$ is 17.6 according to Weyer et al., (2002). The plot of $\mathrm{Nb} / \mathrm{Ta}$ vs. the tetrad effect shows a positive correlation display significant tetrad effects (Fig. 56).

However, the tetrad effect seems not to be mutual with the content of $\mathrm{Na}_{2} \mathrm{O}$ and $\mathrm{Rb} /$ Sr (Fig.57\&58). The absence of coherence between tetrad effect and soda content may indicate insignificant role of the Na-metasomatism in developing the tetrad effect.

The REE tetrad effect was mainly observed in late magmatic differentiation related to strong hydrothermal interactions or deuteric alteration, Dupuy et al. (1992). The high-temperature alteration indicated by REE pattern displaying the tetrad effect albitization resulted from fluid-rock interaction

\section{SPECTROMETRIC RESULTS}

The studied pegmatite samples are inves-

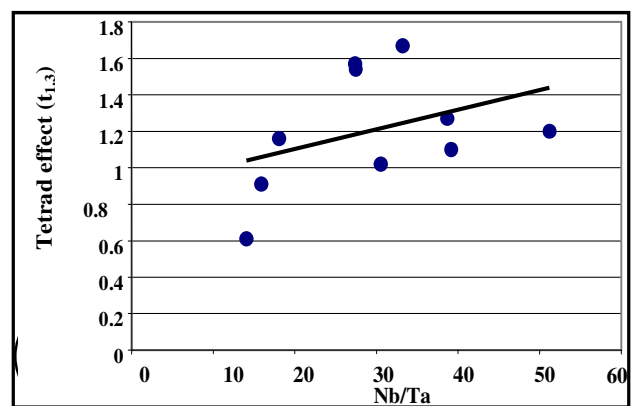

Fig. 56: Tetrad effect vs. $\mathrm{Nb} / \mathrm{Ta}$

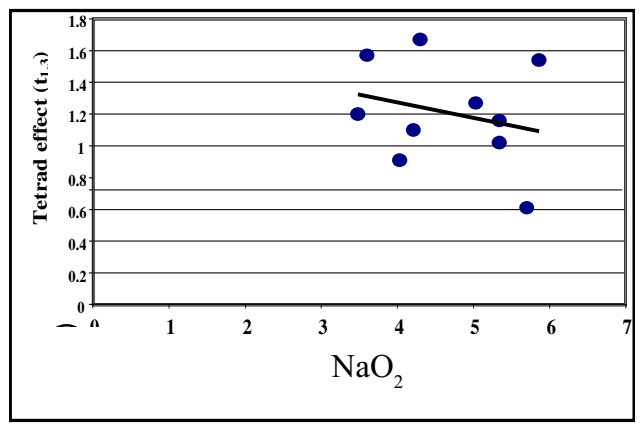

Fig. 57: Tetrad effect vs. $\mathrm{NaO}_{2}$

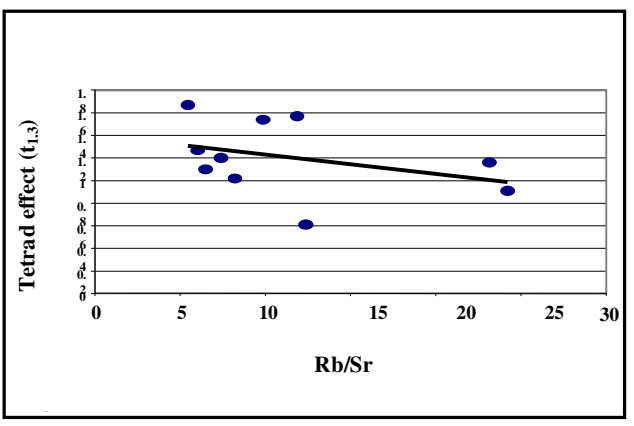

Fig.58:Tetrad effect vs. $\mathrm{Rb} / \mathrm{Sr}$ in pegmatite of Khour Abalea area

tigated radiometrically in the field using RS230 BGO Super-Spec portable radiation detector, handheld unit spectrometer survey meter with high accuracy. The $\mathrm{K}_{40}(\%)$, eU (ppm), eTh (ppm) and eU/eTh (Table.3) are used to outline the radioactivity characteristics of the pegmatites and showing high levels of eU and eTh concentrations.

Detailed spectrometric survey on the study pegmatite revealed their enrichment of eU (49$306 \mathrm{ppm})$ and eTh (76-634 ppm) and the potential anomalous radioactivity is attributed to both magmatic and hydrothermal processes.

The relationship between eU and eTh reveals a positive correlation (Fig.59), which points to coherence between $\mathrm{U}$ and $\mathrm{Th}$. The relationship between eU and eU/eTh shows a weak positive correlation due to syngenetic processes and remobilization of $U$ minerals (Fig.60). The presence of significant thorium in the pegmatite of Khour Abalea gives more support for the syngenetic origin. The relationship between eTh and eU/eTh shows a moderate negative correlation which suggests that $U$ distribution is disturbed by later hydrothermal solution (Fig.61).

The relationship between eTh and eTh/eU showing good positive correlation which suggests that Th distribution is not disturbed by later hydrothermal solution (Fig.62). But the relation between eU and eU/eTh as 
Table3:Representative radioelement distribution of $\mathrm{K} \%$, eU, eTh and eU/eTh of the Khour Abalea pegmatite, South Eastern Desert, Egypt

\begin{tabular}{|c|c|c|c|c|c|c|c|c|}
\hline \multirow{2}{*}{ Sp.No. } & \multicolumn{2}{|c|}{$\mathrm{K}_{40} \%$} & \multicolumn{2}{|c|}{$\mathrm{eU}(\mathrm{ppm})$} & \multicolumn{2}{|c|}{ eTh (ppm) } & \multicolumn{2}{|c|}{ eU/eTh } \\
\hline & Range & Av. & Range & Av. & Range & Av. & Range & Av. \\
\hline 1 & $4.7-5.6$ & 5.2 & $151-170$ & 162 & $82-110$ & 97 & $1.55-1.84$ & 1.69 \\
\hline 2 & $6.2-6.7$ & 6.4 & $89-105$ & 97 & $157-230$ & 199 & $0.46-0.57$ & 0.50 \\
\hline 3 & $5.9-6.5$ & 6.2 & 112.135 & 122 & $176-210$ & 189 & $0.64-0.67$ & 0.65 \\
\hline 4 & $4.5-5.2$ & 4.9 & $120-145$ & 131 & $181-320$ & 237 & $0.45-0.66$ & 0.57 \\
\hline 5 & $5.7-6.2$ & 5.9 & $94-110$ & 103 & $135-220$ & 165 & $0.45-0.75$ & 0.63 \\
\hline 6 & $4.9-5.6$ & 5.2 & $44-59$ & 51 & $63-92$ & 76 & $0.64-0.70$ & 0.67 \\
\hline 7 & $5.2-5.9$ & 5.6 & $78-92$ & 86 & $100-149$ & 126 & $0.62-0.78$ & 0.69 \\
\hline 8 & $4.9-5.7$ & 5.2 & $57-77$ & 66 & $90-145$ & 115 & $0.53-0.63$ & 0.58 \\
\hline 9 & $5.6-5.7$ & 5.7 & $82-105$ & 95 & $145-220$ & 175 & $0.48-0.61$ & 0.55 \\
\hline 10 & $3.9-5.2$ & 4.4 & $83-97$ & 91 & $745-810$ & 769 & $0.11-0.13$ & 0.12 \\
\hline 11 & $4.1-4.8$ & 4.4 & $105-125$ & 113 & $191-260$ & 220 & $0.48-0.55$ & 0.52 \\
\hline 12 & $6.2-7.8$ & 6.9 & $284-325$ & 306 & $572-310$ & 634 & $0.46-0.50$ & 0.49 \\
\hline 13 & $6.2-6.7$ & 6.5 & 133-145 & 139 & $238-310$ & 279 & $0.47-0.56$ & 0.52 \\
\hline 14 & $6.2-6.8$ & 6.5 & $94-105$ & 100 & $225-284$ & 255 & $0.33-0.47$ & 0.40 \\
\hline 15 & $4.1-5.7$ & 4.9 & $65-85$ & 73 & $283-310$ & 294 & $0.23-0.27$ & 0.25 \\
\hline 16 & $4.9-5.6$ & 5.2 & $71-90$ & 81 & $212-295$ & 259 & $0.30-0.33$ & 0.31 \\
\hline 17 & $5.4-6.2$ & 5.9 & $31-69$ & 49 & $67-110$ & 84 & $0.46-0.63$ & 0.57 \\
\hline 18 & $4.9-6.6$ & 5.7 & $55-85$ & 66 & $290-375$ & 331 & $0.19-0.24$ & 0.20 \\
\hline
\end{tabular}

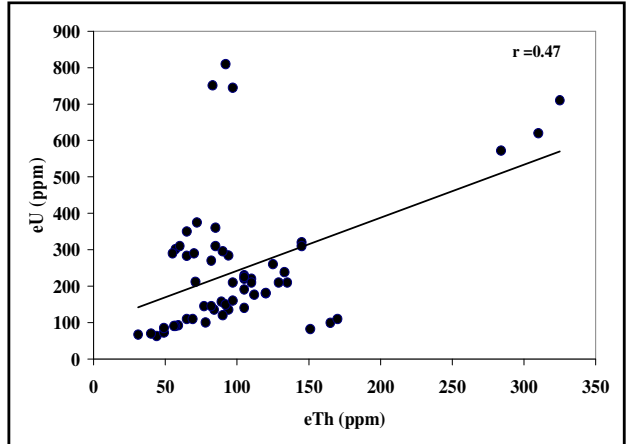

Fig. 59: Binary variation diagram between eTh vs. eU, Khour Abalea pegmatite.

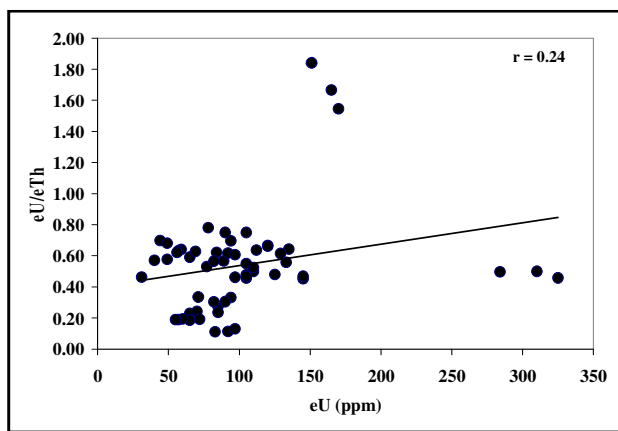

Fig. 60: Binary variation diagram between eTh vs. eU/eTh, Khour Abalea pegmatite.

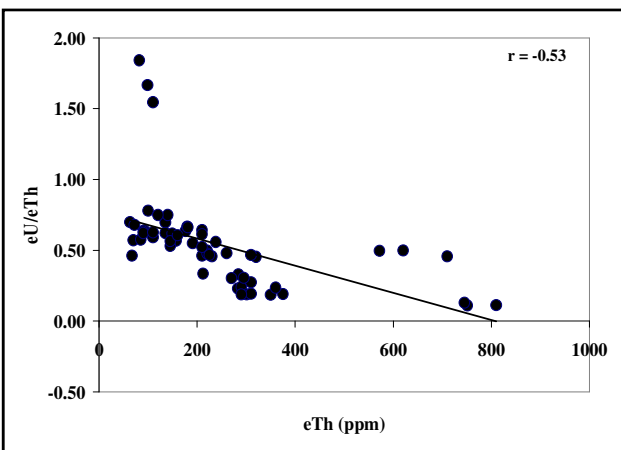

Fig. 61: Binary variation diagram between eTh vs. eTh/eU, Khour Abalea pegmatite.

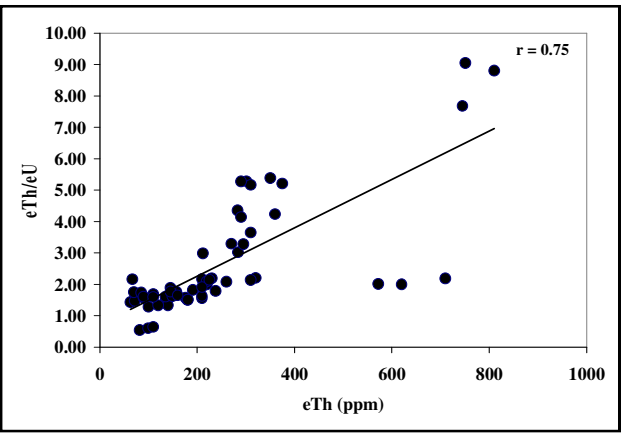

Fig. 62: Binary variation diagram between eU vs. eU/eTh, Khour Abalea pegmatite.

well as K40\% versus eU (Fig.63) and versus Th (Fig.64) are weekly correlated because of the important role that played by hydrothermal solutions beside the alteration processes. 


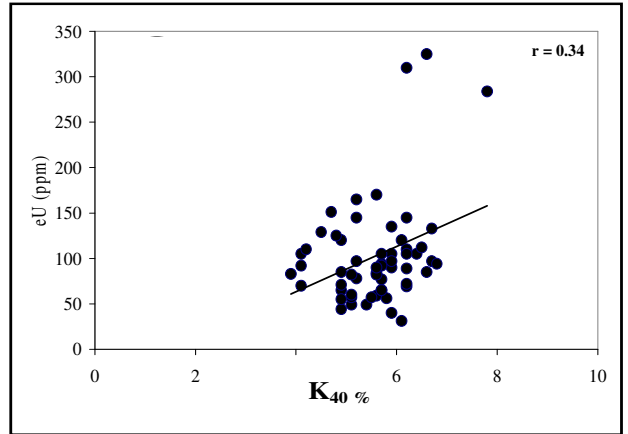

Fig. 63: Binary variation diagram between $\mathrm{K} \%$ vs. eU, Khour Abalea pegmatite.

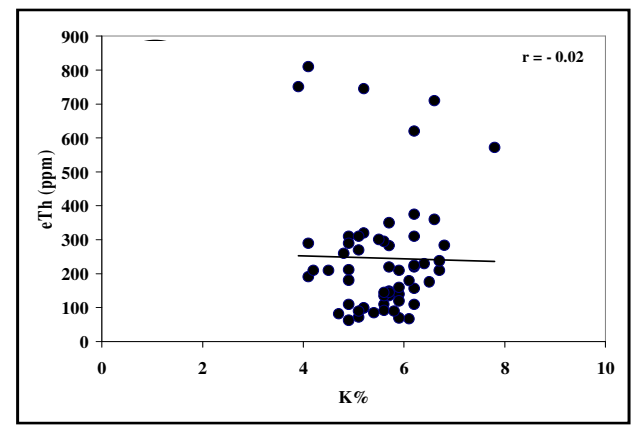

Fig. 64: Binary variation diagram between K\% vs. eTh, Khour Abalea pegmatite

\section{Origin of Secondary Uranium and Thorium -Mineralization}

The origin of the supergene secondary uranium minerals (uranophane, meta-autunite, and kasolite) is mainly related to the alteration of primary minerals by the action of oxidizing fluids and mobilization of uranium and then redeposition in other forms. Cathelineaus and Holluger (1987) stated that the uranium mineralization is affected by the different stages of alteration. These stages of leaching; mobility and redeposition of $U$ are affected by hydrothermal solutions and supergene fluids causing oxidation of the medium.

Uranium and Thorium tend to concentrate in the residual phases and enter the accessory minerals such as zircon, columbite and monazite. Also, they may form minerals of their own such as thorite, uranoanthorite and secondary uranium minerals (Rogers and Adams, 1969). It has been shown that the accessory minerals and their sequence of crystallization play a major role in controlling the geochemical behaviour of uranium and thorium in silicate melts (Simpson et al., 1979). The early crystallization of uranoanthorite would lead to significant U-enrichment in the residual fluids. On the other hand, the early crystallization of zircon and/or xenotime would lead to Th-enrichment in the residual fluids (Pagel, 1982).

Sminov (1984) suggested that the low $\mathrm{Th} /$ $\mathrm{U}$ ratio (less than 3 ) in granite is due to the effect of fluids carrying uranium mineralization. The studied pegmatites have $\mathrm{Th} / \mathrm{U}$ ratio with average of 1.69 indicating high effect of hydrothermal solution. Also, the presence of amazonite K-feldspar tends to enhance the content of $\mathrm{Pb}, \mathrm{U}$ and $\mathrm{Th}$. The accessory minerals such as zircon, monazite, xenotime, samarskite and columbite as well as thorite, uranoanthorite are main sources of the potential radioactivity in the studied pegmatites.

\section{CONCLUSION}

1-Khour Abalea is a U-shaped body and located at the midst part of the mylonitic rocks. It was formed as a result of deep strikeslip faults, some forming shear zones in some trends. The studied pegmatite distributed in two forms in Khour Abalea, veins and scattered pockets. The uranium concentrations in the first is represented by week values (i.e. uranium leached out) while the other has high values because of these pockets of segregated pegmatites distributed along the runoff of the Khour Abalea riching by micas and accessory minerals (Ibrahim et al.,2002 \& 2004).

2-The identified minerals in the studied pegmatites can be grouped into primary uranium minerals represented by uraninite, secondary uranium minerals (kasolite, uranophane, and meta-autunite), thorium minerals 
(thorite and uranothorite), the niobium-tantalum minerals (columbite, ferrocolumbite, euxenite, fergusonite and samarskite), the accessories (zircon, monazite, cassiterite, pyrite and fluorite) and mica (muscovite, phlogopite and fluor-phlogopite) as well as opaques (hematite and goethite).

3-The studied pegmatite (S-type) are calc-alkaline and peraluminous in nature. It is highly fractionated possibly due to hydrothermal alterations. The REEs display clear tetrad affect of M-type accompanied with relative enrichment of the HREE over the LREE and marked negative $\mathrm{Eu}$ anomaly $\left(\mathrm{Eu} / \mathrm{Eu}^{*}\right.$ $=0.03$ to 0.36 ). Hydrothermal alteration during post-magmatic stages being subjected to host rocks is identified through the development of an M-type tetrad effect in the REE pattern of pegmatite. The distinct behaviour of the most popular isovalent elements ratio ( $\mathrm{Zr} / \mathrm{Hf}, \mathrm{Nb} / \mathrm{Ta}$, and $\mathrm{Y} / \mathrm{Ho})$ during hydrothermal alteration seems to be non-chondritic and is no longer exclusive the control of ionic radius and charge. The absence of coherence between tetrad effect and soda and potassic contents may indicate insignificant role of the $\mathrm{Na}$ - and K-metasomatism in developing the tetrad effect. Khour Abalea pegmatites are considered to be the rare element pegmatite class (Černý, 1991 \& 1992) and classified to two types' potassic and sodic pegmatites. They are generally enriched in HREE over LREE attribute to the presence of, zircon, xenotime, monazite, samarskite (enriched-REE) and columbite as well as meta-autunite.

4- Detailed spectrometric survey on the study pegmatite revealed their enrichment of $\mathrm{eU}$ and $\mathrm{eTh}$ and the potential anomalous radioactivity is attributed to both post-magmatic and hydrothermal processes.

\section{REFERENCES}

Abd El Wahed, A.A.; Sadek, A.A.; Abdel Kader, Z.Y., and Motomura \& Watanabe, K., 2007. Petrogenetic relationships between pegmatite and granite based on chemis- try of muscovite in pegmatite wall zones, wadi El Falio, central Eastern Desert. Ann. Geo. Surv. Egypt, XXIX,123-134.

Abd El-Naby, H.H., and Saleh, G.M., 2003. Radioelement distributions in the Proterozoic granites and associated pegmatites of Gabal El Fereyid area, Southeastern Desert, Egypt. J. Appl. Radiation \& Isotopes, 59, 289-299.

Abdalla, H. M., and El Afandy, A. H., 2003. Contrasting mineralogical and geochemical characteristics of two A-type pegmatite fields, Eastern Desert, Egypt, Egypt. Egypt. Mineral., 15, 287-328.

Abdalla, H. M.; Helba, H., and Mohamed, F.H.,1998. Chemistry of columbite-tantalite minerals in rare metal granitoids, Eastern Desert, Egypt. Mineral. Mag., 62, 821-836.

Abdel Monem, A. A., and Hurley, P. M.,1979. $\mathrm{U}-\mathrm{Pb}$ dating of zircons from psammitic gneisses, Wadi Abu Rusheid - Wadi Sikait area, Egypt. Inst. Appl. Geol., Jeddah 3, ( 2), $165-170$.

Ahmed, A. A., 2002. Geology, petrography, geochemistry and radioactivity of Kadabora district,central Eastern Desert of Egypt. Ph. D. Thesis, South Valley Univ., Egypt, 216 p.

Anders, E., and Grevesse, N.,1989. Abundances of the elements: meteortic and solar. Geochim. Cosmochim. Acta, 53, 197214.

Bai, T. B., and Van Groos, A. F. K., 1999. The distribution of $\mathrm{Na}, \mathrm{K}, \mathrm{Rb}, \mathrm{Sr}, \mathrm{Al}, \mathrm{Ge}, \mathrm{Cu}$, $\mathrm{W}, \mathrm{Mo}, \mathrm{La}$ and $\mathrm{Ce}$ between granitic melts and coexisting aqueous fluids. Geochim. Cosmochim. Acta, 63, 1117-1131.

Bau, M.,1996. Controls on the fractionation of isovalent trace elements in magmatic and aqueous systems; evidence from $\mathrm{Y} / \mathrm{Ho}, \mathrm{Zr} /$ Hf, and lanthanide tetrad effect. Contrib. Mineral. Petrol. ,123, 323-333. 
Bau, M., 1999. Scavenging of dissolved yttrium and rare earths by precipitating iron oxyhydroxide; Experimental evidence for Ce oxidation, Y-Ho fractionation, and lanthanide tetrad effect. Geochim. Cosmochim. Acta, 63, 67-77.

Bau, M., and Dulski, P., 1995. Comparative study of yttrium and rare earth elements behavior in fluorine-rich hydrothermal fluids. Contrib. Mineral. Petrol., 119, 213223.

Bau, M.; Dulski, P., and Mo'ller, P., 1995. Yttrium and holmium in South Pacific seawater;Vertical distribution and possible fractionation meachanisms. Chem. Erde, 55, 1-15.

Bowden, P., 1974. Rare earth patterns in peralkaline and associated granites, Lithos.7, No. 1.

Cathelineaus, M., and Holuger, P.,1987. Polyphase metallogenesis of hydrothermal map uranium viens from the southern Armorican massife, France. Proc. Int. Mtg, Nacy, 212-217.

Černý, P.,1991. Rare-element granitic pegmatities. Part I: Anatomy and internal evolution of pegmatitie deposits. Geoscience Canada, 18 (2), 49-67.

Černý, P., and Ercit, T.S.,1989. Mineralogy of niobium and tantalum: Crystal chemical relationships, paragenetic aspects and their economic implications. In: Lanthanides, Tantalum and Niodium (M)( Moller, P.; Cerny, P., and Saupe, F.,Eds.). SpringerVerlag, New York, 27-79.

Černý, P., 1992. Geochemical and petrogenetic features of mineralization in rare-element granitic pegmatites in the light of current research. App. Geochim., 7, 393416.

Clarke, D.B.,1992. The mineralogy of peraluminous granites. A review. Can. Mineral.,19,3-17.
Cuney, M.; Leroy, J.; Volivezo, A.; Daziano, C.; Gambda, B.; Zarco, A. J.; Morello, O.; Ninci, C., and Molina, P.,1989. Metallogenesis of the uranium mineralized Achala granitic complex, Argentina: comparison with Hercynian peraluminous leucogranites of Western Europe. Proc. Tech. Comm. Meetings, Vienna, TECDOC-543, I.A.E.A., Vienna, 211 - 232.

Dawood, Y. H. ; Hesham M.; Harbi , a.; Hamdy, H.; Abd El-Naby, 2010. Genesis of kasolite associated with aplite-pegmatite at Jabal Sayid, Hijaz region, Kingdom of Saudi Arabia. J. Asian Earth Sci., 37 , $1-9$.

Dingwell, D. B.; Hess, D.U., and Romano, C.,1998. Viscosity data for hydrous peraluminous granitic granitic melts: comparison with the metaluminous model. Am. Mineral., 83, 236-239.

Dipak, C.P.; Biswajit, M., and Heinz, J.B.,2006. Mineralogy and geochemistry of pegmatite-hosted Sn-Ta-Nb and Zr-Hlfbearing mineals from the southeaster part of the Baster-Malkangiri pegmatite belt, Central India. Ore Geol. Reviews, 26, 324-342.

Dupuy, C.; Liotard, J., and Dostal, J.,1992. $\mathrm{Zr} / \mathrm{Hf}$ fractionation in intraplate basaltic rocks;Carbonate metasomatism in the mantle source. Geochim. Casmochim. Acta, 56, 2417-2423.

El Aassy, I. E.; Botros, N. H.; Ibrahim, M. E.; Hammed, M. S., and Hassan, M. A., 1993. A new beryl occurrence in Sinai, Egypt. Min. Soc. Egypt, 5, 1-10.

El Aassy, I. E.; Shazly, A. G.; Hussein, H. A.; Heikal, M. T. S., and El Gaby, M. M.,1997. Pegmatites of Nubeiba-Dahab area, West Gulf of Aqaba, Sinai, Egypt; Field aspets, mineralogy, geochemistry and radioactivity. The $3^{\text {rd }}$ Conf. Geochem., Spe., 3-4.

El Dougdoug, A.; Takla, M. A.; Surour, A.; Hussein, A., and Elaraky, E.,1997. Miner- 
alogy and origin of Wadi Sikait Emerald, Southeastern Desert, Egypt. The $3^{\text {rd }}$ Conf. Geochem., Spe., 3-4.

Ercit, T.S.,2005. REE-enriched granitic pegmatites. In: Rare-element Geochemistry and Ore Deposits (Linnen, R.L., and Samson, I.M.,Eds.). Geol. Assoc. Canala Short Course Notes ,17, 257-296.

Erlank, A.J.; Marchant, J.W.; Cardoso, M.P., and Ahrens, L.H.,1978. Zirconium. In: handbook of Geochemistary(Wedepohl, K. h.,Ed.), Springer, 11/4, 40 B-O.

Ferguson, R. B.,1955. Crystallography of synthetic $\mathrm{YTaO} 4$ and fused fergusonite (abs). Geol. Soc.Am., Bull.,66,:1557p.

Fuertes-Fuente, M.; Martin-Izard, A.; Boiron, M. C., and Vinuela, J. M.,2000. P-T path and fluid evolution in the Franqueira granitic pegmatite, central Galicia, northwestern Spain. Canad.Mineral., 38, 11631175 .

Gorman, D. H., and Nuffield, E. W.,1955. Studies of radioactive compound: uranophane and beta-uranophane. Am. Min., $40,634-645$.

Harris, N. B. W., and Inger, S.,1992. Trace element modeling of pelite- derived granites. Contrib. Mineral. Petrol., 110, 46-56.

Harris, N. B. W.; Pearce, J. A., and Tiudie, A. C., 1984. Geochemical characteristics of collision zone magmatism. In: Collision tectonics (Ries, A. C. , and Coward, M. P. Eds.). Geol. Soc. London Spec. Publ., $19,67-81$.

Hassan, M.A.,1973. Geology and geochemistry of radioactive columbite-bearing psammitic gneiss of Wadi Abu Rusheid. South Eastern Desert, Egypt. Ann. Geol. Surv. Egypt., III, 207-225.

Heinrich, E. W,1958. Mineralogy and geology of radioactive raw materials. McGrawHill Book Co. Inc., New York, Toronto,
London.

Heinrich, E. W.,1962. Radioactive columbite. Amer, Mineral., 47, 1363-1379. 1000, 000. Ann. Geol. Surv. Egypt., II, $1-15$.

Ibrahim, M. E.; El Tokhi, M. M.; Saleh G. M., and Rashed, M. A.,2006. Lamprophyre bearing-REEs, South Eastern Desert, Egypt. $7^{\text {th }}$ Intern. Conf. Geochem., Fac. Sci., Alex. Univ., Alex., Egypt, 6-7 Sept.

Ibrahim, M. E.; Saleh, G. M., and Abd El-Naby, H. H., 2001. Uranium mineralization in the two-mica granite of Gabal Ribdab, south Eastern Desert, Egypt. Aool. Radiat. Isot., $55 / 6,123-134$.

Ibrahim, M. E.; Saleh, G. M.; Amer, T.; Mahmoud, F. O.; Abu El Hassan, A. A,; Ibrahim, I. H.; Aly, M. A.; Azab, M. S.; Rashed, M. A.; Khaleal, F. M., and Mahmoud, M. A., 2004. Uranium and associated rare metals potentialities of Abu Rusheid brecciated shear zone II, south Eastern Desert, Egypt. (Internal report).

Ibrahim, M. E.; Shalaby, M. H., and Amar, S. E., 1996. Preliminary studies on some uranium and thorium bearing pegmatites at Gabal Abu Dob, central Eastern Desert. Egypt. Proc. Egypt. Acadm. Sci., 47, 173188.

Ibrahim, M.; Saleh, G.; Rashed, M., and Watanabe, K.,2007c. Base metal mineralization in lamprophyre dykes at Abu Rusheid area, south Eastern Desert, Egypt. The $10^{\text {th }}$ Inter. Min. Petrol., and Metall. Eng. Conf., Assuit Univ., 31-40.

Ibrahim, M.E.,1999. On the Occurrence of U, REE-bearing samarskite, Abu Dob area, Central Eastern Desert, Egypt. Proc. Egypt. Aca. Sci.,49p.

Ibrahim, M.E.; Abd El-Wahed, A. A.; Rashed, M. A.; Khaleal, F. M.1.; Mansour, G. M., and Watanabe, K.,2007a. Comparative study between alkaline and calc-alkaline lamprophyres, Abu Rusheid area, south 
Eastern Desert, Egypt. The $10^{\text {th }}$ Inter. Min., Petrol., and Metall. Eng. Conf., Assuit univ., 99-115.

Ibrahim, M.E.; Saleh, G. M.; Hassan, M. A.; El-Tokhi, M. M., and Rashed, M. A.,2007b. Geochemistry of lamprophyres bearing uranium mineralization, Abu Rusheid area, south Eastern Desert, Egypt. The $10^{\text {th }}$ Inter. Min., Petrol., and Metall. Eng. Conf., Assuit univ., 41-55.

Ibrahim, M.E.; Saleh, G.M.; Abd El Naby, H.H.; Amer, T.; Mahmoud, F.O.; Abu El Hassan, A.A.;Ibrahim, I.H.; Aly, M.A., Azab, M.S.; Rashed, M.A.; Khalel, F.M., and Mahmoud, M.A.,2002. Uranium and associated rare metals potentialities of $\mathrm{Abu}$ Rusheid brecciated shear zone I, south Eastern Desert, Egypt, (Internal Report), $107 \mathrm{p}$.

Irber, W.; Forster, H.-J.; Hecht, L.; Moller, P., and Morteani, 1997. Experimental, geochemical. Mineralogical, and O-isotope constrains on the late-magmatic history of the Fichtelgebirge granites (Germany). Geol. Rdsch.86 (suppl.), 110-124.

Irber, M.E.W., 1999. The lanthanide tetrad effect and its correlation with $\mathrm{K} / \mathrm{Rb}, \mathrm{Eu} / \mathrm{Eu}^{*}$, $\mathrm{Sr} / \mathrm{Eu}, \mathrm{Y} / \mathrm{Ho}$, and $\mathrm{Zr} / \mathrm{Hf}$ of evolving peraluminous granite suites. Gechim. Cosmochim. Acta,63, 489-508.

Irvine, T.N., and Boragar, W.R.A., 1971. A guide to the classification of the common volcanic rocks. Can, J. Earth Sci., 8,523548.

Jolliff, B. L.; Papike, J. J., and Shearer, C. K.,1992. Petrogenetic relationships between pegmatite and granite based on geochemistry of muscovite in pegmatite wall zones, Black Hills, South Dakota, USA. Geochim. Cosm. Acta, 56, 1915-1939.

Linnen, R.L.,1998. Experimental constraints on the association of $\mathrm{Li}$ with $\mathrm{Ta}$ in granitic pegmatites. Abstract and programme, $17^{\text {th }}$
General Meeting IMA, August, Toronto, A146p.

London, D.,1992. The application of experimental petrology to the genesis and crystallization of granitic pegmatites. Canad. Mineral., 30, 499-450.

Mason, D.,1966. Principles of geochemistry. $3^{\text {rd }}$ (ed.), John Wiley and Sons, New York, $310 \mathrm{p}$.

Masuda, A.; Kawakami, O.; Dohmoto, Y., and Takenaka, T.,1987. Lanthanide tetrad effects in nature; two mutually opposite types, W and M. Geochem. J. ,21, 119124.

Meyer, C., and Hemley, J. J.,1967. Wall rock alteration in geochemistry of ore deposits(Barnes, H. L.,Ed.). New York, 166 - 235 p., Mineralogists, 15, 287-328.

Monecke, T.; Kempe, U.; Monecke, J.; Sala, M., and Wolf, D.,2002. Tetrad effect in rare earch element distribution patterns: a method of quantification with application to rock and mineral samples from graniterelated rare metal deposits. Geochim. Cosmochim. Acta ,66,1185-1196.

Nesbitt, H. W., and Young, G. M., 1984. Prediction of some weathering trends of plutonic and volcanic rocks based up on thermodynamic and kinetic consideration. Geochim. Cosmochim. Acta., 48, 1523 -1534 .

Nesbitt, H. W., and Young, G. M.,1989. Formation and Diagenesis of Weathering profiles. J. Geol., 97, 129 - 147.

Pagel, M.,1982. The mineralogy and geochemistry of uranium, thorium and rare elements in two radioactive granites of Vosages . France. Min, Mag. ,46/339,149161.

Petro, W.L.; Vogel, T.A., and Wilband, J.T., 1979. Major elements chemistry of plutonic rock suites from compressional and ex- 
tensional plate boundaries. Chem. Geol., 26, 217-235.

Ragab, 2010. Geochemistry and Radioactivity of Mineralized Pegmatite from Abu Rusheid Area, South Eastern Desert, Egypt. Earth Sci. ,22 .No3,

Rashed, M.A., 2005. Geologic studies on a new occurrence of Nuclear Materials in Abu Rusheid Area, South Eastern Desert, Egypt. Ph.D. Thesis, Fac.Sci. (Demiatta), Mansoura Univ.

Raslan, M.F.; Ali, M.A., and El Feky, M. G.,2010a. Mineralogy and radioactivity of pegmatites from South Wadi Khuda area, Eastern Desert, Egypt. Chan. J. Geochem., 29,343-354.

Raslen, M.f.; El Shall, H.E.; Omer, S.A., and Daher, A.M.,2010b. Mineralogy of polymetallic mineralized pegmatite of Ras Baroud Granite, Central Eastern Desert. Egypt. J. Mineral. Petrol. Sci., 105/3, 123-134.

Rogers, J. J. W., and Adams, J. A. S., 1969. Uranium and thorium. In: Handbook of geochemistry, VII-3, 92-B-1 to 92-0-8 and $90-\mathrm{B}-1$ to $90-0-5$ (Wedephol, K. H., Ed.). Springer Venleg.

Saleh, G. M., 1997.The potentiality of uranium occurrences in Wadi Nugrus Area, South Eastern Desert, Egypt. Ph.D. Thesis, Mansoura univ. Egypt, 171 p.

Saleh. M.G.; El Galy, M.M., and Obeid, M.A.,2007. Geochemical characteristics and spectrometric prospecting in the muscovite-bearing pegmatites and granites, southeastern Aswan, Egypt. Chin. J. Geochem., 27, 9-20.

Salem, I. A.; Heikal, M. T. S., and Ashmawy, M. H., 1998. Rod Ashab mica-bearing pegmatite, Eastern Desert, Egypt: A model for the derivation of anatexis. Proc. $1^{\text {st }}$ Symp. "Geol. Of the Pre-Cret. And Develop. In Egypt”. Zagazig, 1-26.
Schroll, E.,1976. Analytische Geochemie., II 374p,Stuttgart, Enke.

Shand , S.J.,1951. Eruptive Rocks. John Wiely, New York.

Shapiro, L., and Brannock, W. W.,1962. Rapid analysis of silicate, carbonate and phosphate rocks. U. S. Geol. Surv. Bull, 1144-A, 56p.

Shaw, D.M., 1968. A review of K-Rb fractionation trends by covariance analysis. Geochim. Cosmochim. Acta ,32,573-601.

Shearer, C. K.; Papike, J.J., and Laui, J.c., 1985.Chemistray of potassium feldspars from three zones pegmatites, Black Hills, South Dakaota: Impllications concerning pegmatite evolution. Gochim. Cosmochim. Acta ,49, 663-673.

Simmons, W.; Karen, L.; Webber, Alexander U.; Falster \& James W., and Nizamoff ,2003. Pegmatology: pegmatite mineralogy, petrology and petrogenesis, department of geology and geophysics. Rubellite Press/Karen L. Webber, 176p.

Simmov, S.D.,1984. U-Th-RE mobility in granitic environments at the hydrothermal stage. IAEA, Vienna, 215-246.

Simpson, P. R.; brown, G. C.; Plant, J., and Ostle, D.,1979. Uranium mineralization and granite magmatism in the British Isles. In: Theoretical and practical aspects of uranium geology (Bowie, S. H. U.; Fyfe, W. S.; Ostle, D.;Plant, J., and Simpson, P. R.,Eds.). Trans. Roy. Soc., London, A.291,385-412.

Sosa, G.M.; Augshurger, M.S., and Pedregosa, J.,2002. Columbite-group minerals from rare metal granitic pegmatities of the Sierra de San Luis, Argentina. Europ. J. Mineral., 14, 627-636.

Surour, A.A.; Omar, S.A., and Zunic, T.B.,2004. Cation ordering and chemistry of cryptically zoned columbite from 
Ras Baroud rare-metal pegmatites, Central Eastern Desert, Egypt. $6^{\text {th }}$ Inter. Conf. Geochem., Alexandria Univ., Egypt, 777795.

Takahashi, Y.;Yoshida, H.; Sato, N.; Hama, K.; Yusa, Y., and Shimizu, H.,2002. Wand M-type tetrad effects in REE patterns for water-rock systems in the Tono uranium deposit, central Japan. Chem. Geol., 184, 311-335.

Taylor, S.R., and Mclennan, S.M.,1985. The Continental Crust ; its composition and evolution. BlackWell, Oxford.

Wades, J., and Wood ,B.J., 2001. The earth's "missing" niobium may be in the core. Nature, 409, 75-78.

Webster, J.D.; Thomas, R.; Rhede, D.; Forster, H.J., and Seltmann, R.,1997. Melt inclusions in quartz from an evolved peraluminous pegamatite: geochemical evidence for strong tin enrichment in fluorine-rich and phosphorus-rich residual liquids. Geochim. Cosmochim. Acta, 61, 2589-2604.

Weyer, S.; Munker, C.; Rehkamper, M., and Mezger, K.,2002. Determination of ultralow $\mathrm{Nb}, \mathrm{Ta}, \mathrm{Zr}$ and $\mathrm{Hf}$ concentrations and the chondrite $\mathrm{Zr} / \mathrm{Hf}$ and $\mathrm{Nb} / \mathrm{Ta}$ ratios by isotope dilution analyses with multiple connector ICP-MS. Chem. Geol., 187(3), 295-313.

Zagorsky, V.Y., and Peretyazhko, I.S., 2006. The Malkhan granite-pegmatite system; intrusion of chemically heterogenous pegmatite magma. Goldschmidt Conf. Abstracts, A729p.

Zhao, Z. H.; Wang, Z. G.; Zpu, T. R., and Masuda, A.,1993. The REE, isotopic composition of $\mathrm{O}, \mathrm{Pb}, \mathrm{Sr}$ and $\mathrm{Nd}$ petrogenesis of granitoids in the Altai region In: Progress of solid-earth sciences in northern Xinjiang, China (Tu, G.Z., Ed.). Scence Press. Beijing. 239-266 p.

\footnotetext{
الصفات المعدنية وأصل صخور البجماتيث لخور الأبيليا، جنوب الصحراء الثرقية المصرية مصطفى السيد محمد درويش

يتخذ خور الأبيليا شكل حرف (U) ويقِع بداخل الصخور التهشمية لمنطقة أبورشيد وقد يكون هذا الخور كنتيجة

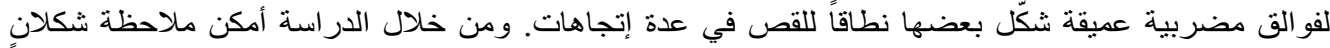

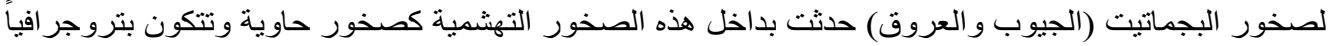

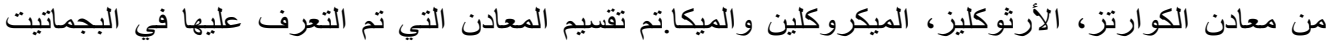

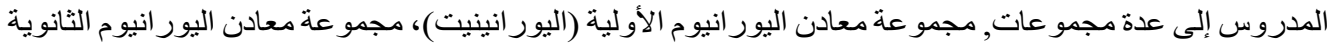

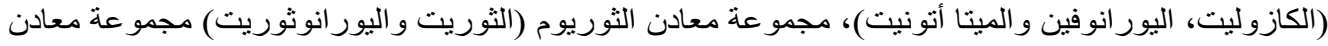

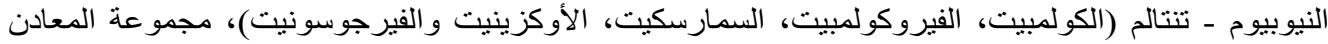

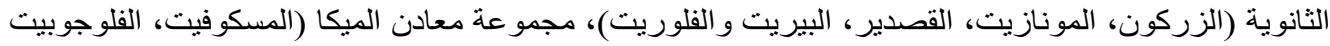

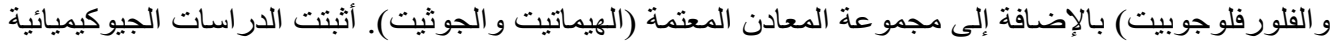

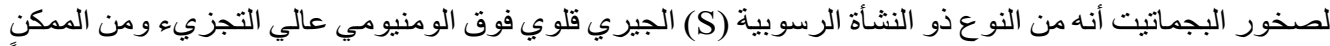

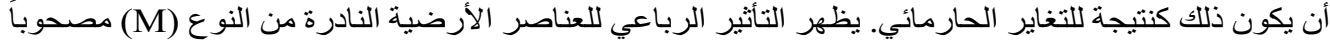

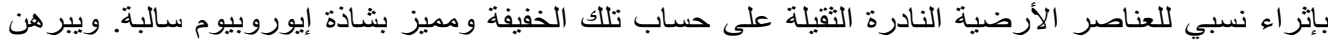

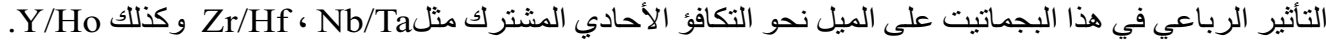

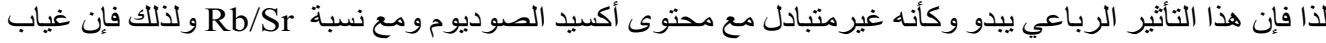

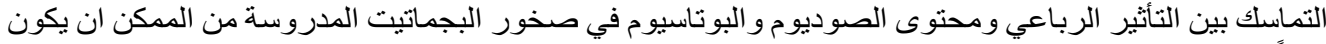

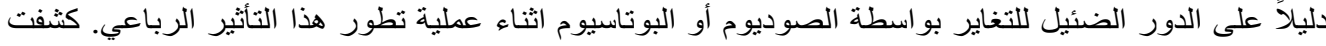

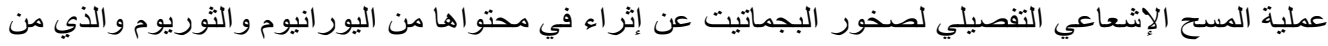
الممكن ان يُعزى إلى العمليات الصهيرية الصئية والحارمائية.
} 